WATER WITHDRAWAL AND USE IN MARYLAND, 1987

by Judith C. Wheeler

U.S. GEOLOGICAL SURVEY

Open-File Report 90-572

Prepared in cooperation with the

MARYLAND WATER RESOURCES ADMINISTRATION

and the

MARYLAND GEOLOGICAL SURVEY

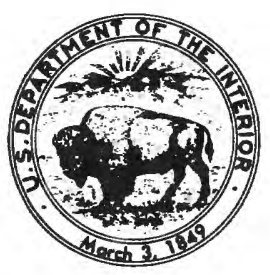

Towson, Maryland 


\section{U.S. DEPARTMENT OF THE INTERIOR}

MANUEL LUJAN, JR., Secretary

\section{U.S. GEOLOGICAL SURVEY}

Dallas L. Peck, Director

For additional information write to:

\section{District Chief}

U.S. Geological Survey

208 Carroll Building

$8600 \mathrm{La}$ Salle Road

Towson, Maryland 21204
Copies of this report can be purchased from:

U.S. Geological Survey

Books and Open-File Reports Section

Denver Federal Center, Box 25425

Denver, Colorado 80225 


\section{CONTENTS}

\section{Page}

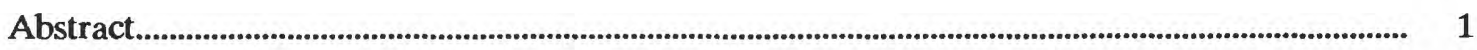

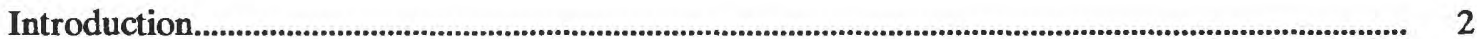

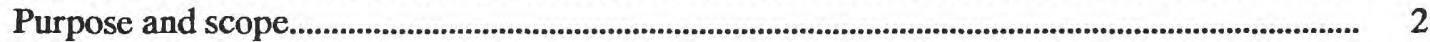

Methods of data collection and estimation......................................................................................... 3

Population and water-use trends.................................................................................................... 4

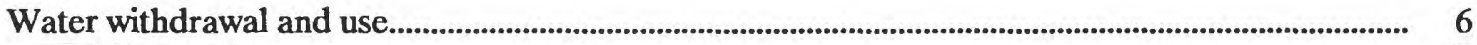

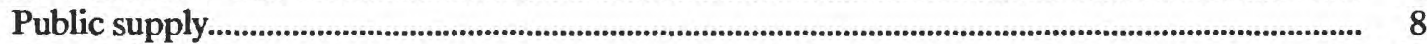

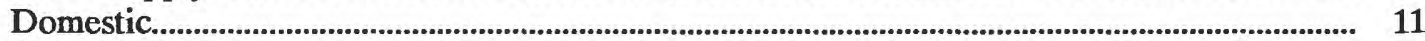

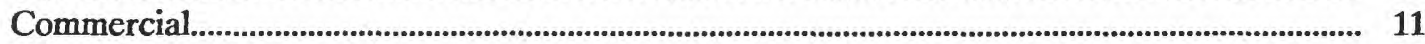

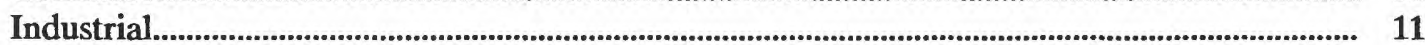

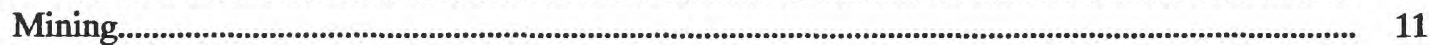

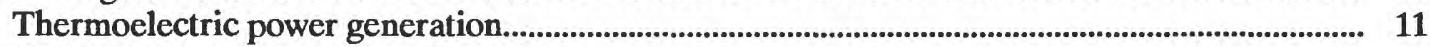

Hydroelectric power generation................................................................................................... 14

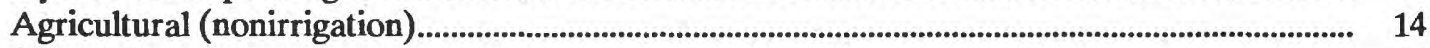

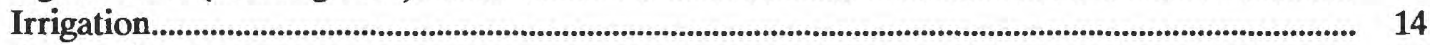

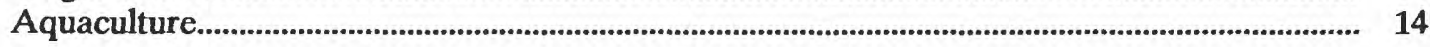

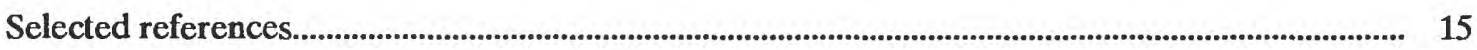

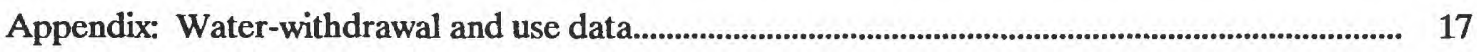

\section{ILLUSTRATIONS}

Figure 1. Map showing the counties of Maryland............................................................................... 2

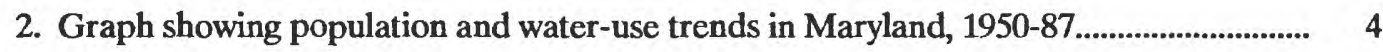

3. Map showing freshwater withdrawals in Maryland, by county, 1987............................... 6

4. Bar charts showing freshwater withdrawals and percentage for each type

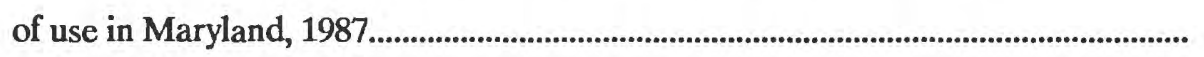

5. Maps showing fresh surface-water and ground-water withdrawals in

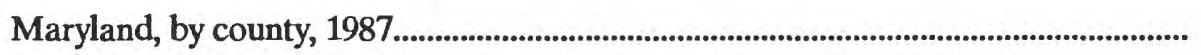




\section{ILLUSTRATIONS-Continued}

Figure 6. Map and bar chart showing fresh surface-water and ground-water

withdrawals by principal drainage basin in Maryland, 1987.

7. Maps and bar chart showing ground-water withdrawals by principal aquifers in Maryland, 1987.

\section{TABLES}

Table 1. Population and water use in Maryland, 1987.

2. Total water withdrawals (excluding hydroelectric power generation) in Maryland, by county, 1987.

3. Public-supply withdrawals and deliveries in Maryland, by county, 1987.

4. Domestic water withdrawals (self-supplied) and deliveries from public suppliers in Maryland, by county, 1987.

5. Commercial freshwater withdrawals (self-supplied) and deliveries from public suppliers in Maryland, by county, 1987.

6. Industrial water withdrawals (self-supplied) and deliveries from public suppliers in Maryland, by county, 1987.

7. Mining water withdrawals in Maryland, by county, 1987

8. Thermoelectric power generation water withdrawals in Maryland, by county, 1987

9. Hydroelectric power generation water use in Maryland, by county, 1987

10. Agricultural (nonirrigation) water withdrawals in Maryland, by county, 1987. 26

11. Irrigation water withdrawals in Maryland, by county, 1987 27

12. Aquaculture water withdrawals in Maryland, by county, 1987 


\title{
WATER WITHDRAWAL AND USE IN MARYLAND, 1987
}

\author{
By Judith C. Wheeler
}

\section{ABSTRACT}

This report presents the results of a study by the U.S. Geological Survey, in cooperation with the Maryland Water Resources Administration and the Maryland Geological Survey, to summarize the amounts of fresh and saline water withdrawn and used in Maryland during 1987.

During 1987, about 1,480 million gallons per day (Mgal/d) of freshwater was withdrawn from the surfaceand ground-water resources of Maryland. Of this amount, $1,235 \mathrm{Mgal} / \mathrm{d}(83$ percent) was used in the State and $245 \mathrm{Mgal} / \mathrm{d}$ (17 percent) was transferred to surrounding States and the District of Columbia, for water supply. About 7.71 Mgal/d of freshwater was imported from bordering States for use in Maryland. In addition, about $6,210 \mathrm{Mgal} / \mathrm{d}$ of saline surface water was withdrawn and used in the generation of electricity in Maryland.

The majority of freshwater withdrawals ( 84 percent) were from surface-water sources. Most fresh surface water was withdrawn and used in the Potomac drainage basin (about $893 \mathrm{Mgal} / \mathrm{d}$ ), whereas most ground water (about $176 \mathrm{Mgal} / \mathrm{d}$ ) was withdrawn and used in the Upper Chesapeake drainage basin. The Potomac Group aquifers provided the most ground water $(58.5 \mathrm{Mgal} / \mathrm{d})$.

Ten water-use categories comprised the major demands on the surface-water and ground-water resources of the State in 1987:

- Public supply--794 Mgal/d was withdrawn and delivered to residents (for domestic use), commercial establishments, and industries. Public suppliers delivered water to 82 percent of the total population. Baltimore City received the largest public-supply deliveries $(150 \mathrm{Mgal} / \mathrm{d})$ in 1987.

- Domestic--493 Mgal/d (426 Mgal/d was received from public suppliers and about $67.3 \mathrm{Mgal} / \mathrm{d}$ was self-supplied).

- Commercial--90.6 Mgal/d (about $66.9 \mathrm{Mgal} / \mathrm{d}$ was received from public suppliers and 23.8 $\mathrm{Mgal} / \mathrm{d}$ was self-supplied).

- Industrial--140 Mgal/d (64.6 Mgal/d was received from public suppliers and $75.7 \mathrm{Mgal} / \mathrm{d}$ was self-supplied). Industries also used $287 \mathrm{Mgal} / \mathrm{d}$ of brackish or saline surface water and about $80.7 \mathrm{Mgal} / \mathrm{d}$ of reclaimed sewage water.

- Mining--24.8 Mgal/d of freshwater and about 15.3 Mgal/d of saline surface water was withdrawn. Nearly all the saline water (14.8 $\mathrm{Mgal} / \mathrm{d}$ ) was for dredging operations.
- Thermoelectric power generation--427 Mgal/d of freshwater was withdrawn. In addition, $6,210 \mathrm{Mgal} / \mathrm{d}$ of saline surface water was used primarily for cooling condensers.

- Hydroelectric power generation (instream water use)--19,200 Mgal/d of freshwater was used for the production of electricity. Although the amount of water diverted by some plants was considerable, the amount consumed was considered negligible.

- Agricultural (nonirrigation)--10.4 Mgal/d of freshwater was used primarily for livestock watering, feedlots, and dairy operations.

- Irrigation (including irrigating farm crops, golf courses, parks, and nursery plants)-- 52.4 $\mathrm{Mgal} / \mathrm{d}$ of freshwater was used. Of this amount, $47.4 \mathrm{Mgal} / \mathrm{d}$ was used for irrigating farm crops. In addition, about $5.17 \mathrm{Mgal} / \mathrm{d}$ of brackish surface water was used for farm irrigation.

- Aquaculture--6.11 Mgal/d of freshwater was used primarily for raising fish; $5.91 \mathrm{Mgal} / \mathrm{d}$ of saline water was used primarily for raising crabs and oysters. 


\section{INTRODUCTION}

Maryland has a total land and water area of $12,303 \mathrm{mi}^{2}$ (square miles) and is divided into 23 counties and Baltimore City (fig. 1). The State has abundant surface- and ground-water resources. As the demand for water increases, however, stress is placed on these resources. Efficient water-resource management depends, in part, on the collection of water-withdrawal and use data. Once compiled, these data are valuable in determining the effects of present withdrawals on the State's water resources and on current water-use patterns, and in anticipating the effects of future water demands. This study was done in cooperation with the Maryland Water Resources Administration (WRA) and Maryland Geological Survey.

\section{Purpose and Scope}

This report summarizes the amounts of fresh and saline water withdrawn and used in Maryland in 1987. The data are discussed briefly and presented in graphs, tables, and maps, by counties, drainage basins, and aquifers.

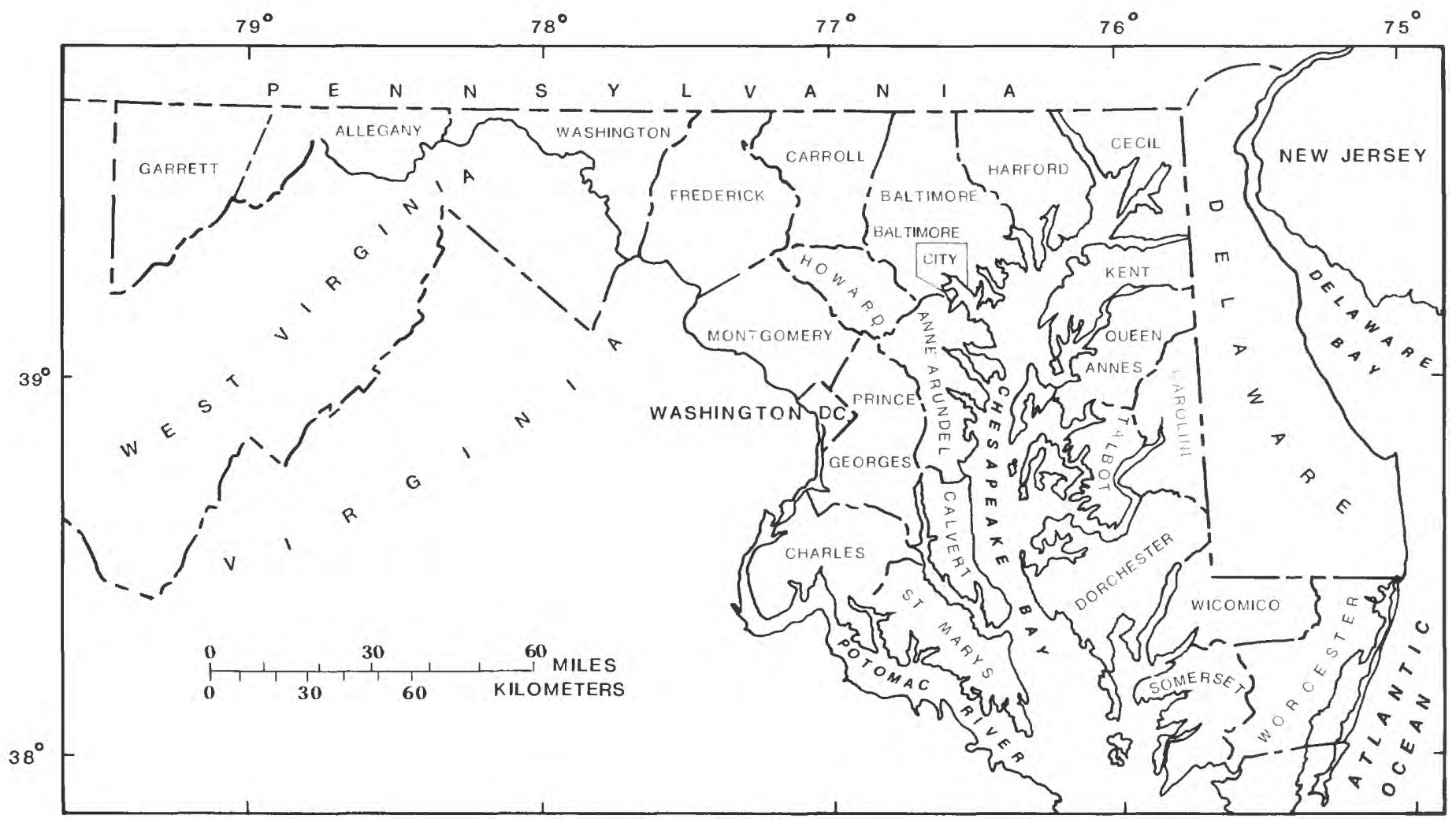

BASE MAP FROM U.S. GEOLOGICAL SURVEY 1:1,000,000

Figure 1.--Counties of Maryland. 
The amount of water withdrawn from sources in each county has been distinguished from the amount of water used in each county. Water withdrawals in each county include all water withdrawn or transferred to another county or State. Water use is defined as the amount of water actually used in each county, including (1) water withdrawn for use in the county and (2) water transferred in from another county or State. Selfsupplied water and water delivered from public-supply systems are combined for each category.

The water-use categories discussed in this report are public supply, domestic, commercial, industrial, mining, thermoelectric power generation, hydroelectric power generation, agricultural (nonirrigation), irrigation, and aquaculture. Water withdrawn by a public or private water utility and delivered to a variety of users is designated as a "public supply." If a public supply is not available or is not used, the water is classified as "self-supplied." Homes and small communities relying on individual wells are classified as domestic self-supplied water use. Thermoelectric power generation is defined as electric energy generated in steam-electric plants including those that use nuclear fuel. Water used for the generation of electricity by hydroelectric power plants is discussed here but the quantities of water used are not included in the freshwater totals because this use is considered "instream" water use--that is, water use takes place within the stream channel.

\section{Methods of Data Collection and Estimation}

Most of the water-use data on public suppliers, commercial and industrial facilities, mines, and thermoelectric power plants were obtained from pumpage reports submitted to WRA by users withdrawing $0.01 \mathrm{Mgal} / \mathrm{d}$ (million gallons per day) or more. Annual and monthly withdrawal data are stored in a computerized data base by WRA. The U.S. Geological Survey, in cooperation with WRA and the Maryland Department of the Environment (MDE), also maintains a site-specific water-use data base, the Maryland State Water-Use Data System (SWUDS) that is designed to store water-withdrawal data from the WRA data base and returnflow data from MDE for users that withdraw or return $0.01 \mathrm{Mgal} / \mathrm{d}$ or more. The WRA's data base and SWUDS were used in the preparation of this report. Water-use data for users of less than $0.01 \mathrm{Mgal} / \mathrm{d}$ were obtained from the average daily permit allocations as stated in water-appropriation and use permits issued by WRA.

Water-use data on domestic, agriculture, irrigation, and hydroelectric power generation were estimated using the foliowing methods:

Self-supplied domestic withdrawal was estimated by determining the number of people not served by public suppliers (based on data obtained from individual county water and sewerage plans), subtracting that number from the total population for each county (compiled from Maryland Department of State Planning, 1987), and multiplying the result by the estimate of per capita water use. Per capita water use in Maryland was estimated by WRA to be $80 \mathrm{gal} / \mathrm{d}$ (gallons per day).

Hydroelectric power generation water use was estimated based on annual generation data (Energy Information Administration, 1987a, 1987b, 1988a, and 1988b) and a coefficient of water used per KWh (kilowatt hour) (Weisberg, S.B., Martin Marietta Environmental Systems, written commun., 1986).

Agricultural (nonirrigation) water use was estimated tused on the number of farm animals in each county (U.S. Department of Commerce, 1988) and the amount of water used per animal category (U.S. Environmental Protection Agency, 1973, p. 15). It was assumed th si grazing animals such as cattle and sheep relied on surface water for supply, and poultry, hogs, and dairy cnws relied on ground water.

Irrigation water use was estimated frrm the number of acres irrigated, using a water application rate of 0.9 (acre-ft/acre)/yr (acre-foot per acre fer year) or about $818 \mathrm{gal} / \mathrm{d}$ (Carr, L.E., Maryland Cooperative Extension Service, oral commun., 1989!. 
The total population of Maryland was approximately 4,500,000 in 1987 (compiled from Maryland Department of State Planning data, 1987). Population and water-use facts for 1987 are presented in table 1. About 82 percent of the total population (3.68 million people) were served by public-supply systems in 1987. Surface water was used by 67 percent of the population; ground water was used by 33 percent of the population.

Population and water-use trends for Maryland from 1950 to 1987 are shown in figure 2. In 1950, about 2.34 million people used approximately $400 \mathrm{Mgal} / \mathrm{d}$ of freshwater. Both population and water use increased steadily through the 1950's and 1960's. From 1970 to 1987, however, the rate of population growth slowed, only increasing from 3.92 million people in 1970 to 4.5 million in 1987. Water use, during the same period, leveled off in the early 1970 's at about $1,500 \mathrm{Mgal} / \mathrm{d}$, then decreased over the rest of the decade. In 1980, water use was about $1,400 \mathrm{Mgal} / \mathrm{d}$. Possible explanations for the decrease in water use include changing economic trends, particularly declining water use among certain industries, and increased use of conservation techniques and fixtures. However, water use increased from 1985 to 1987 , from about $1,400 \mathrm{Mgal} / \mathrm{d}$ to about $1,480 \mathrm{Mgal} / \mathrm{d}$, primarily due to increases in withdrawals for cooling purposes by power plants, for irrigation, and for public-supply distribution.

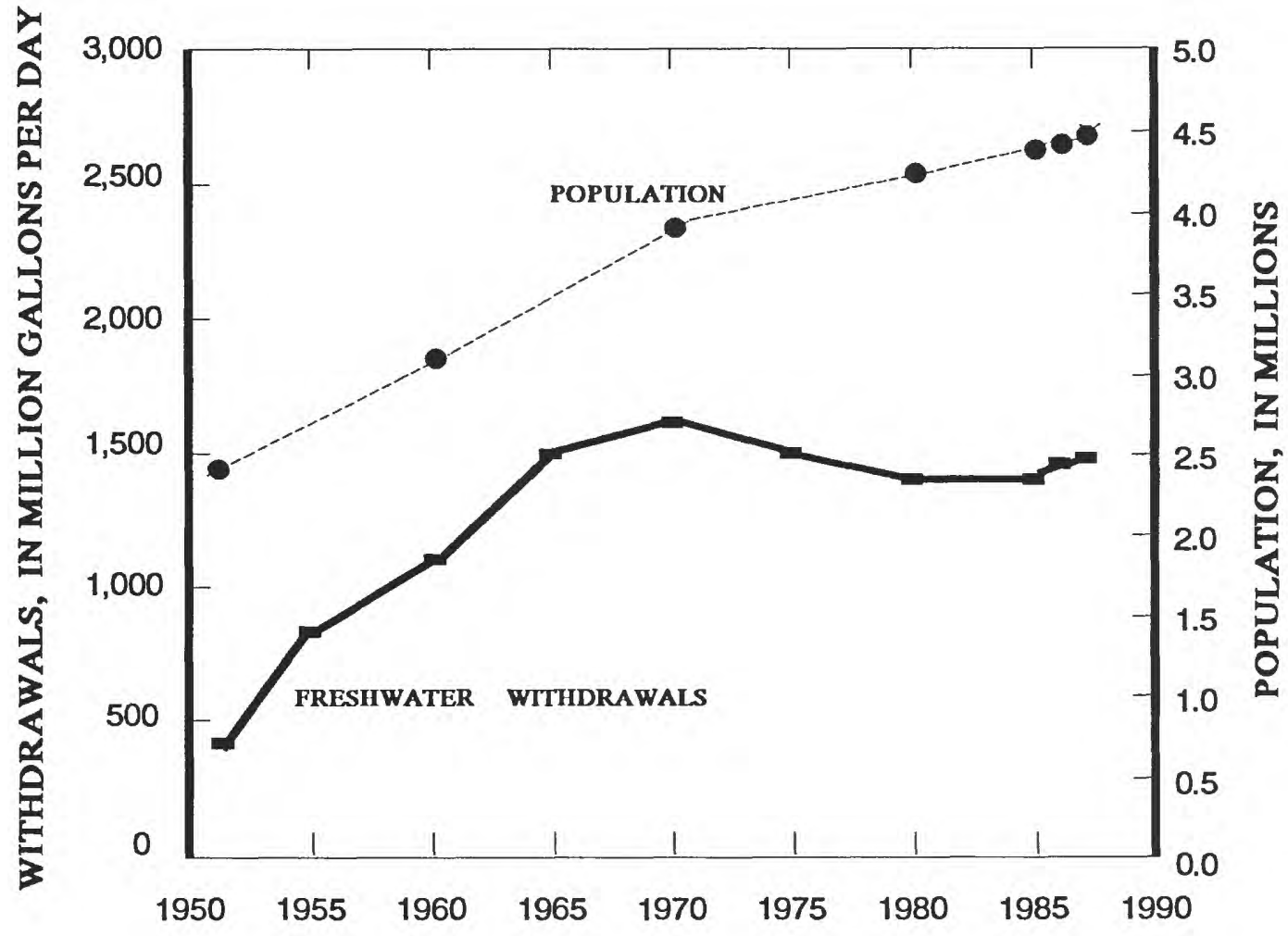

Figure 2.--Population and water-use trends in Maryland, 1950-87. 
Table 1.--Population and water use in Maryland, 1987

[Population data rounded to three significant figures and may not add to totals because of independent rounding. Percentages rounded to two significant figures]

Total population:

Population served by public-supply systems

Percentage of population served

Population served by self-supplied systems

Percentage of population self-supplied

Surface-water supply:

Percentage of total population served by surface water

Number served by public-supply systems

Percentage of total population

Number served by self-supplied systems

Percentage of total population

Ground-water supply:

Percentage of total population served by ground water

Number served by public-supply systems

Percentage of total population

Number served by self-supplied systems 


\section{WATER WITHDRAWAL AND USE}

During 1987 , approximately 1,480 Mgal/d of freshwater was withdrawn from Maryland's surface- and ground-water sources. Of this amount, $1,235 \mathrm{Mgal} / \mathrm{d}$ ( 83 percent) was used in the State and $245 \mathrm{Mgal} / \mathrm{d}$ (17 percent) was transferred to surrounding States and the District of Columbia, for water supply. Conversely, about 7.71 Mgal/d of freshwater was imported from bordering States for use in Maryland.

Freshwater withdrawals by county are shown in figure 3. The largest water withdrawals (greater than $100 \mathrm{Mgal} / \mathrm{d}$ ) were in Montgomery and Baltimore Counties. These counties provide the water sources for the public suppliers that serve the Baltimore City and District of Columbia metropolitan areas. The smallest water withdrawals were in Baltimore City and Howard County because the main public-supply sources for Baltimore City are located in Baltimore County, and because Howard County is served primarily by the Baltimore City public-supply system and the Washington Suburban Sanitary Commission (WSSC) system (water sources are in Montgomery and Prince Georges Counties).

Freshwater withdrawals by use are summarized in figure 4. Tables 2-12 (located in the appendix at the end of the report) present withdrawal and use data, by county, for the 10 major categories of use. A summary of withdrawals by county is shown in table 2 .

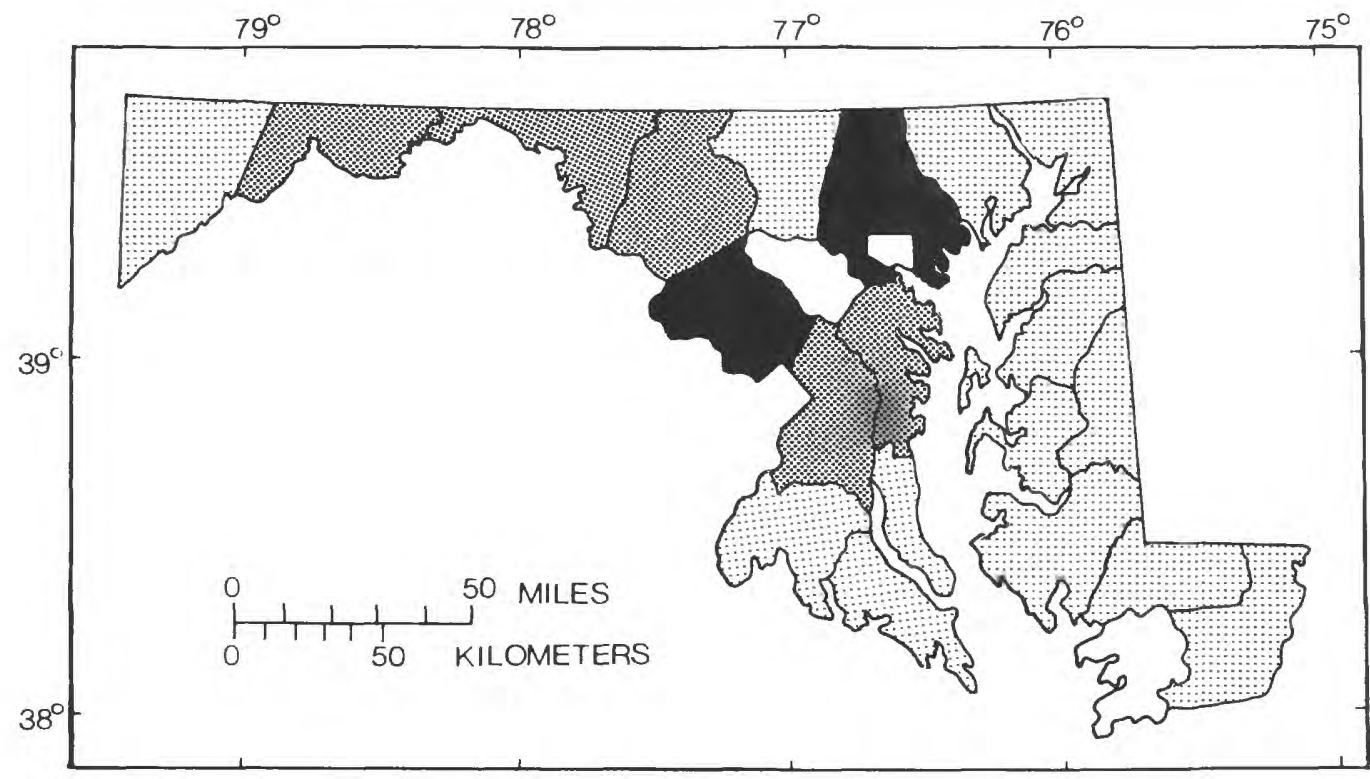

\section{EXPLANATION}

FRESHWATER WITHDRAWALS,

IN MILLION GALLONS PER DAY
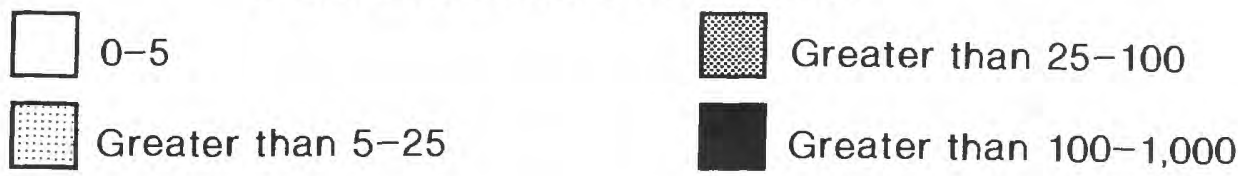

Figure 3.--Freshwater withdrawals in Maryland, by county, 1987. 


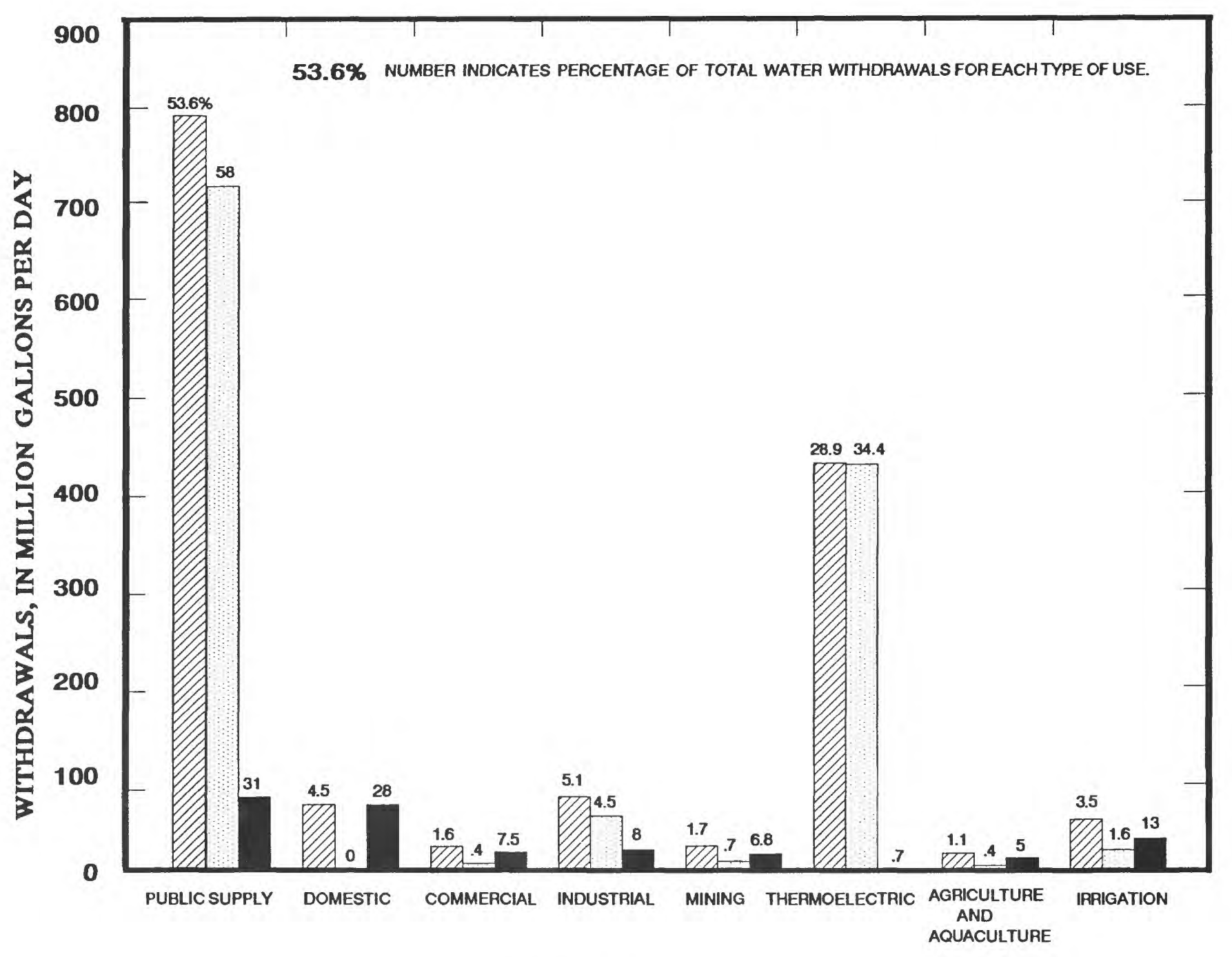

\section{EXPLANANTION}

TOTAL FRESHWATER WITHDRAWALS.

TOTAL: 1.480 Million gallons per day

FRESH SURFACE-WATER WITHDRAWALS.

TOTAL: $1,240 \mathrm{Mgal} / \mathrm{d}$.

FRESH GROUND-WATER WITHDRAWALS.

TOTAL: $239 \mathrm{Mgal} / \mathrm{d}$.

Figure 4.--Freshwater withdrawals and percentage for each type of use in Maryland, 1987. 
A comparison of total fresh surface- and ground-water withdrawals by county is shown in figure 5 . Approximately 84 percent $(1,240 \mathrm{Mgal} / \mathrm{d})$ of the freshwater withdrawn in Maryland in 1987 came from surfacewater sources compared to 16 percent $(239 \mathrm{Mgal} / \mathrm{d})$ from ground-water sources. Most fresh surface-water withdrawals (more than $25 \mathrm{Mgal} / \mathrm{d}$ ) occurred in Montgomery, Baltimore, Washington, Allegany, and Prince Georges Counties (table 2), whereas most ground-water withdrawals (more than $25 \mathrm{Mgal} / \mathrm{d}$ ) occurred in Anne Arundel County.

The largest drainage basins in Maryland are the Potomac and the Upper Chesapeake (fig. 6). About 72 percent of total fresh surface-water withdrawals occurred in the Potomac basin. During 1987, about 893 $\mathrm{Mgal} / \mathrm{d}$ of fresh surface water was withdrawn and used in this basin compared to $339 \mathrm{Mgal} / \mathrm{d}$ (about 27 percent) withdrawn and used in the Upper Chesapeake basin. In addition, about $15.3 \mathrm{Mgal} / \mathrm{d}$ of fresh surface water was withdrawn in the Potomac basin and transferred to the Chesapeake basin for use; conversely, $36 \mathrm{Mgal} / \mathrm{d}$ of fresh surface water was withdrawn in the Upper Chesapeake basin, then transferred to the Potomac basin for use. Less than 1 percent of fresh surface water was withdrawn in the remaining three basins (Monongahela, Susquehanna, and Delaware).

About 74 percent (176 Mgal/d in 1987) of total ground-water withdrawals occurred in the Upper Chesapeake basin compared to about 24 percent (57 Mgal/d in 1987) withdrawn in the Potomac basin. Only about 2 percent of total ground-water withdrawals occurred in the remaining three basins.

Estimated percentages of ground-water withdrawals by principal aquifers for 1987 are shown in figure 7. The map in the figure shows the geographic distribution of the principal aquifers in Maryland (U.S. Geological Survey, 1990, p. 294) with a generalized hydrogeologic section (A-A') of the aquifers most used in the State. The Potomac Group aquifers provided the most ground water, $58.5 \mathrm{Mgal} / \mathrm{d}$ (about 24 percent), followed by the Columbia aquifer with $49 \mathrm{Mgal} / \mathrm{d}$ (about 21 percent). The least amount of water was withdrawn from the Newark Group aquifers with about $3.3 \mathrm{Mgal} / \mathrm{d}$ (less than 2 percent).

\section{Public Supply}

The largest amount of water withdrawn, $794 \mathrm{Mgal} / \mathrm{d}$ (54 percent of total freshwater withdrawals; fig. 4), was by public-supply systems (municipalities, county and town systems, and private utilities). Water was delivered to a variety of users, including residents (domestic use), commercial establishments, and industries (table 3). Most public suppliers in central and western Maryland rely on surface-water sources. The largest user of surface water for public supply in the State is Baltimore City. During 1987, about $150 \mathrm{Mgal} / \mathrm{d}$ were withdrawn for use by the city. In addition, the city supplied about $117 \mathrm{Mgal} / \mathrm{d}$ to parts of Baltimore, Howard, Anne Arundel, and Carroll Counties. Another large user of surface water for public supply in Maryland is WSSC, which withdrew $168 \mathrm{Mgal} / \mathrm{d}$ during 1987 and delivered water to most of Montgomery and Prince Georges Counties and part of Howard County.

The Potomac River in Maryland is used as a source of water by several public suppliers in Virginia and West Virginia and by the Washington Aquaduct, which delivers water to the District of Columbia. In 1987, about $48 \mathrm{Mgal} / \mathrm{d}$ of fresh surface water was withdrawn from the river and transferred to these States for use, and nearly $197 \mathrm{Mgal} / \mathrm{d}$ was withdrawn for public-supply deliveries to the District.

Some municipalities in Maryland obtained all or part of their water supply from bordering States, including Cumberland in Allegany County, which received 7.28 Mgal/d of water from Pennsylvania in 1987; Brunswick in Frederick County, which received about $0.08 \mathrm{Mgal} / \mathrm{d}$ from springs located in Virginia; and Delmar in Wicomico County, which received $0.35 \mathrm{Mgal} / \mathrm{d}$ from wells located in Delaware.

Most public suppliers that rely on ground-water sources are located in the eastern and southern part of Maryland. The largest ground-water withdrawals for public-supply deliveries are in Anne Arundel County (about 32.1 Mgal/d during 1987). In the counties east of Chesapeake Bay, all public suppliers rely on ground water. 

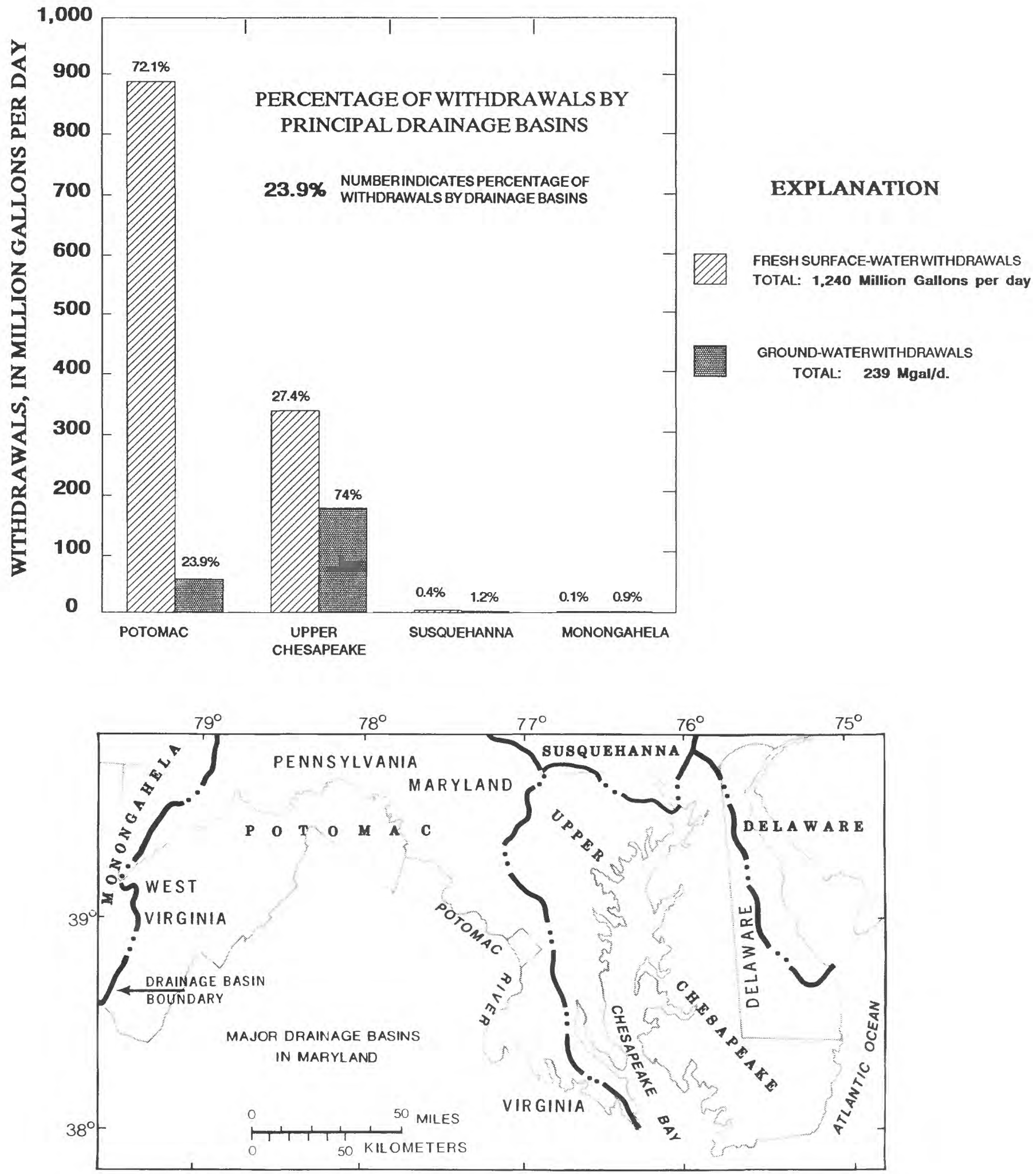

Figure 6.--Fresh surface-water and ground-water withdrawals by principal drainage basin in Maryland, 1987. 


\section{Domestic}

Domestic water users in Maryland receive water from public-supply systems and from self-supplied sources (table 4). During 1987, total use (withdrawals and deliveries) was $493 \mathrm{Mgal} / \mathrm{d}$, of which $426 \mathrm{Mgal} / \mathrm{d}$ was delivered by public suppliers to 82 percent of the total population. The remaining 18 percent of the population withdrew about $67.3 \mathrm{Mgal} / \mathrm{d}$ from privately owned wells. The amount of surface water used for domestic purposes was considered to be negligible, therefore all self-supplied water withdrawn for domestic use was assumed to be from ground-water sources.

\section{Commercial}

Commercial water users, including educational institutions and military installations, receive water from public-supply systems and from privately owned wells. Total commercial use during 1987 was $90.6 \mathrm{Mgal} / \mathrm{d}$ (table 5), of which about $66.9 \mathrm{Mgal} / \mathrm{d}$ (74 percent) was provided by public suppliers and about $23.8 \mathrm{Mgal} / \mathrm{d}$ (26 percent) was self-supplied.

\section{Industrial}

Maryland is located within a regional manufacturing belt which extends along the eastern seaboard of the United States. Both heavy and light industries are important in the State's economy. Heavy industries include steel mills, shipyards, petroleum refineries, chemical plants, and truck assembly lines. Some of the prominent light industries include food processing, printing, publishing, and clothing manufacturing. Water used by industries is both self-supplied and received from public-supply systems. Major water uses include washing and separation processes, cooling (industrial machinery and refrigeration), boiler make-up, product manufacturing, and dust control. During 1987, about $140 \mathrm{Mgal} / \mathrm{d}$ of freshwater was used by industries in Maryland (table 6). Of that amount, $75.7 \mathrm{Mgal} / \mathrm{d}$ or 54 percent was self-supplied and $64.6 \mathrm{Mgal} / \mathrm{d}$ (46 percent) was provided by public suppliers. Industries also used $287 \mathrm{Mgal} / \mathrm{d}$ of brackish or saline surface water (containing more than 1,000 milligrams per liter of dissolved solids) (Hem, 1970, p. 219) and about $80.7 \mathrm{Mgal} / \mathrm{d}$ of reclaimed sewage water.

\section{Mining}

Mining is a significant economic activity in Maryland. The commercially important mineral resources extracted are those used for building materials and fuels. The leading commodities are bituminous coal, stone, sand, and gravel. Water withdrawn in mining operations is primarily for dewatering and mineral washing. During 1987, 24.8 Mgal/d of freshwater was withdrawn for mining purposes (table 7). Of that amount, $8.23 \mathrm{Mgal} / \mathrm{d}$ was from surface-water sources and $16.5 \mathrm{Mgal} / \mathrm{d}$ was from ground-water sources. An additional $15.3 \mathrm{Mgal} / \mathrm{d}$ of brackish or saline water was withdrawn, of which $14.8 \mathrm{Mgal} / \mathrm{d}$ was for dredging operations.

\section{Thermoelectric Power Generation}

Fourteen thermoelectric power plants operate in Maryland; 13 are fossil-fueled and 1 is nuclear powered. Freshwater use by the plants during 1987 was $427 \mathrm{Mgal} / \mathrm{d}$, of which about $426 \mathrm{Mgal} / \mathrm{d}$ was from surface water and 1.6 Mgal/d from ground water (table 8). In addition, $6,210 \mathrm{Mgal} / \mathrm{d}$ of saline surface water was used by the plants. Most of the surface water (more than 95 percent) was used for cooling condensers, of which more than 98 percent was returned to the water source. 

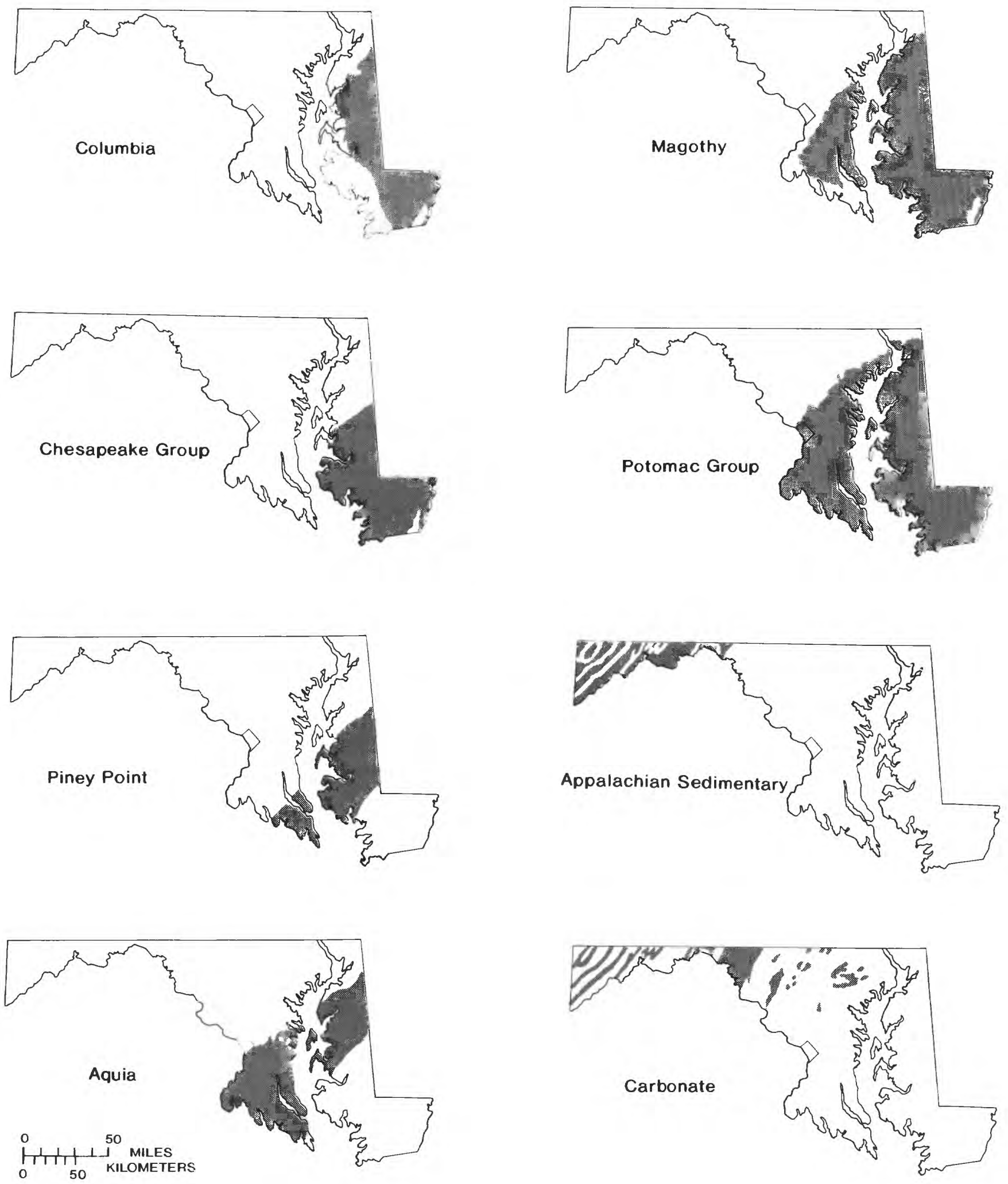

\section{AQUIFERS}

Figure 7.--Ground-water withdrawals by principal aquifers in Maryland, 1987. 

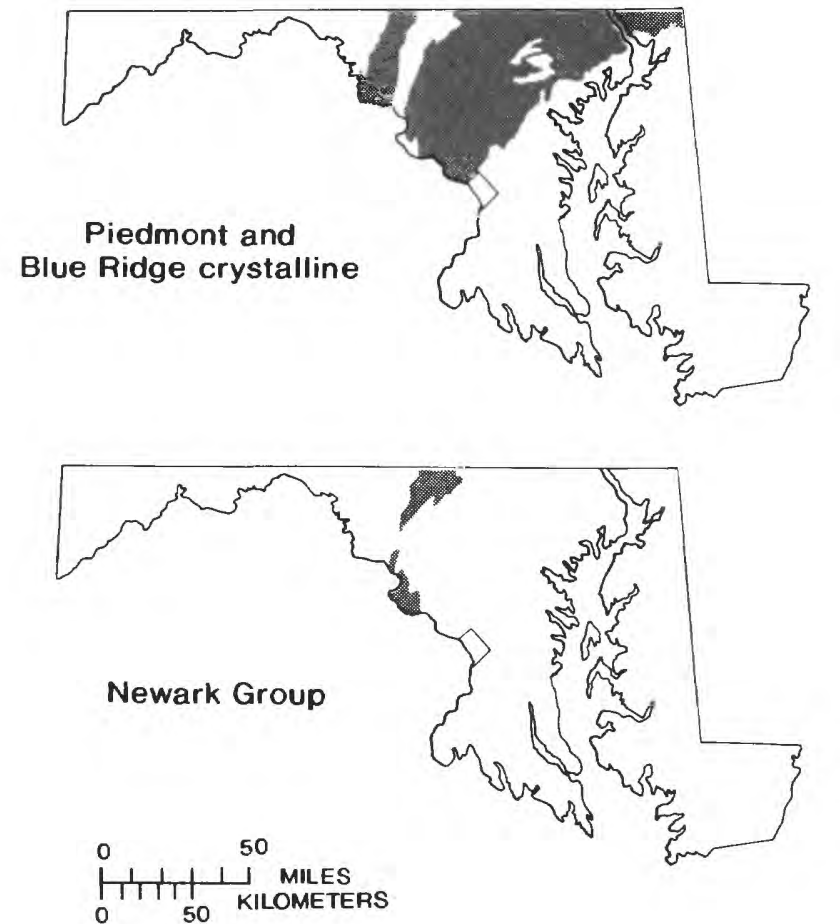

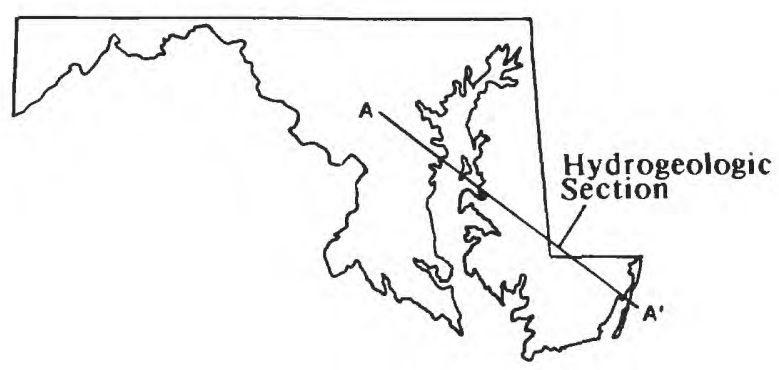

Principal aquifers shown in hydrogeologic section

Piedmont and Blue Ridge crystalline (1)

Potomac Group (2)

Magothy (3)

Not a principal aquifer (4)

Aquia (5)

Piney Point (6)

Chesapeake Group (7)

Columbia ( 8 )

FEET $1.000^{\mathrm{A}}$

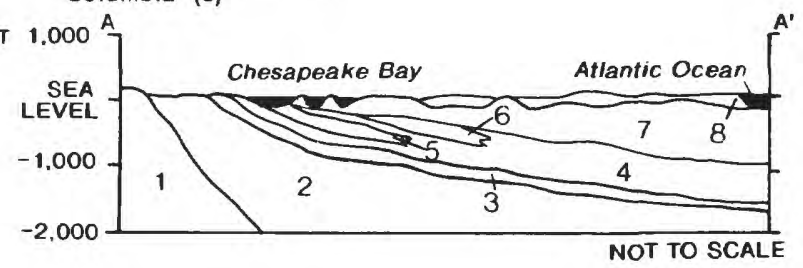

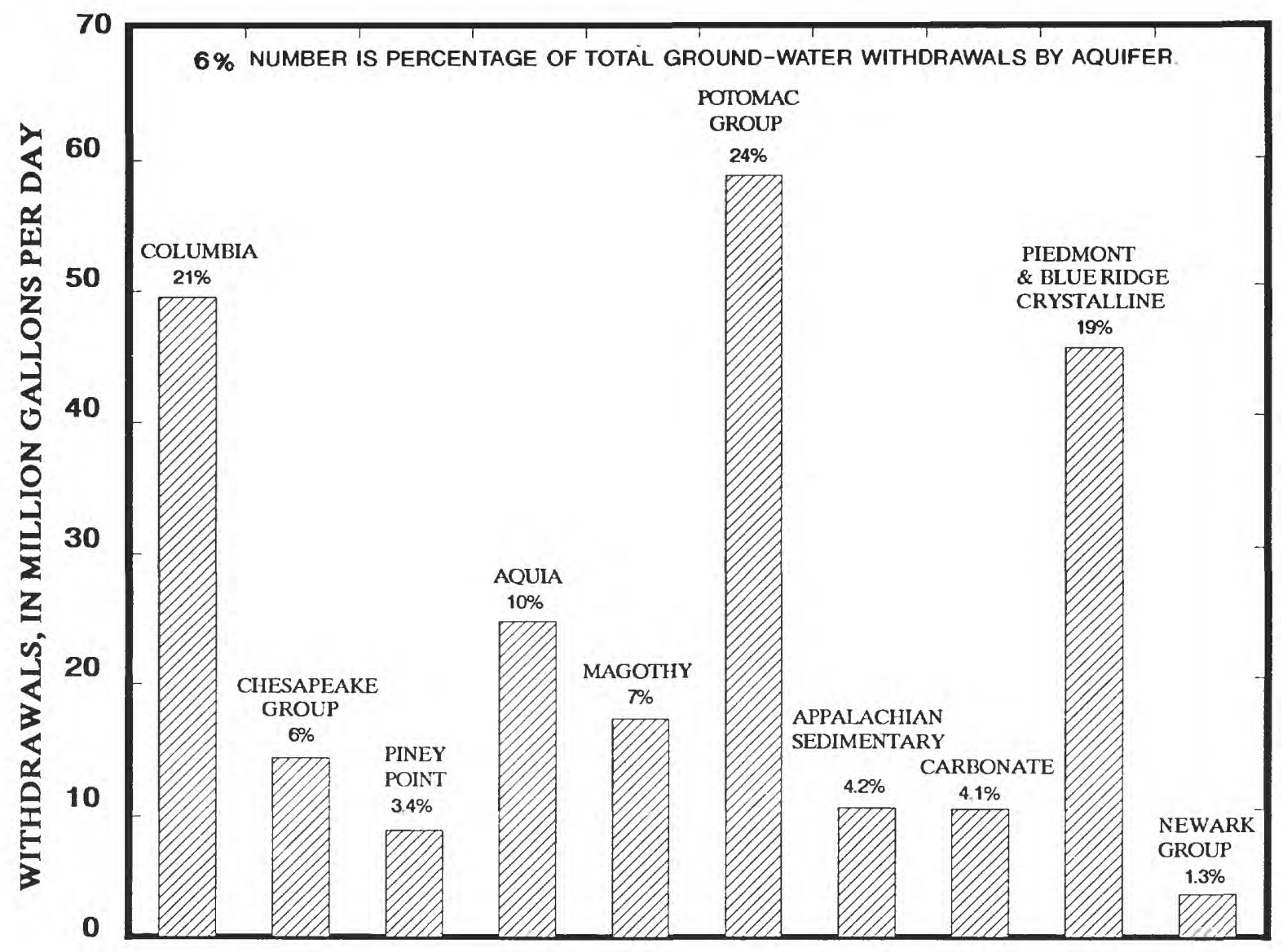

Figure 7.--Ground-water withdrawals by principal aquifers in Maryland, 1987. Continued 


\section{Hydroelectric Power Generation}

Water used for the generation of electricity by hydroelectric power plants is discussed here but the quantities of water used are not included in the freshwater totals because this use is considered "instream" water use--that is, water use takes place within the stream channel. Twelve dams are currently producing or are licensed to produce hydroelectric energy in Maryland (Weisberg and Rose, 1985, p. 1). During 1987, about $19,200 \mathrm{Mgal} / \mathrm{d}$ of freshwater passed through these plants for the production of electricity (table 9). Although the amount of water diverted by some plants to produce electricity is enormous, the amount consumed is negligible--some water is evaporated during the generation process and from storage reservoirs.

\section{Agricultural (nonirrigation)}

During 1987, about $10.4 \mathrm{Mgal} / \mathrm{d}$ of freshwater was used for agricultural (nonirrigation) activities, mainly livestock watering, feedlots, and dairy operations; $2.45 \mathrm{Mgal} / \mathrm{d}$ was from surface-water sources and $7.96 \mathrm{Mgal} / \mathrm{d}$ from ground-water sources (table 10). The major types of livestock raised in Maryland are poultry, cattle, dairy cows, hogs, and sheep. The four counties (Dorchester, Somerset, Wicomico, and Worcester) of the lower Eastern Shore account for about 34 percent of total agricultural receipts in the State, because this area is one of the nation's leading producers of broiler chickens (Di Lisio, 1983, p. 80).

\section{Irrigation}

Freshwater used for irrigating farm crops, commercial, municipal, and institutional lawns and parks, golf courses, and nursery plants was estimated to be $52.4 \mathrm{Mgal} / \mathrm{d}$ in 1987 (table 11). Of this amount, $47.4 \mathrm{Mgal} / \mathrm{d}$ was used for irrigating farm crops including corn, soybeans, tobacco, grains, tomatoes, and melons. In addition, $5.17 \mathrm{Mgal} / \mathrm{d}$ of brackish surface water was used for farm irrigation. A total of about 64,200 acres of cropland were irrigated in the State in 1987 , of which 57,450 acres or about 89 percent were located in the eight counties east of the Chesapeake Bay. Fresh surface water was used to irrigate 23,400 acres $(20.1 \mathrm{Mgal} / \mathrm{d})$ and ground water was used to irrigate $34,314 \mathrm{acres}(32.3 \mathrm{Mgal} / \mathrm{d})$. Caroline County had the largest percentage of irrigated acreage in the State, with about 29 percent or $2.65 \mathrm{Mgal} / \mathrm{d}$ withdrawn for irrigation, followed by Dorchester County with 24 percent or $12.02 \mathrm{Mgal} / \mathrm{d}$.

\section{Aquaculture}

Aquaculture, also known as fish farming or fish culture, is the controlled production of finfish, shellfish, and aquatic plants in fresh and saline environments (Maryland Department of Agriculture, 1988). In Maryland, the aquaculture industry includes ornamental fish, oysters, soft-shell crabs, crawfish, trout, and aquatic plants. During 1987, 6.11 Mgal/d of freshwater was withdrawn for aquacultural purposes in the State, of which 1.84 $\mathrm{Mgal} / \mathrm{d}$ was from surface-water sources and $4.27 \mathrm{Mgal} / \mathrm{d}$ was from ground water (table 12). In addition, 5.91 $\mathrm{Mgal} / \mathrm{d}$ of saline water was used for this purpose. 


\section{SELECTED REFERENCES}

Booth, Nan, 1984, Maryland residential water statistics: University of Maryland, Cooperative Extension Service Fact Sheet 383, College Park, Maryland, 2 p.

Carr, L.E., 1987, The 1986 Maryland irrigation survey: University of Maryland, College Park, Maryland, 7 p.

Di Lisio, J.E., 1983, Maryland, a geography: Boulder, Colorado, Westview Press, 233 p.

Energy Information Administration, 1987a, Electric Power Quarterly, January-March 1987: U.S. Department of Energy, DOE/EIA-0397/1Q, p. 60-236.

1987b, Electric Power Quarterly, April-June 1987: U.S. Department of Energy, DOE/EIA-0397/2Q, p. 58-234.

1988a, Electric Power Quarterly, July-September 1987: U.S. Department of Energy, DOE/EIA-0397/3Q, p. 65-257.

1988b, Electric Power Quarterly, October-December 1987: U.S. Department of Energy, DOE/EIA-0397/4Q, p. 69-260.

Hem, J.D., 1970, Study and interpretation of the chemical characteristics of natural water: U.S. Geological Survey Water-Supply Paper 1473, 363 p.

MacKichan, K.A., 1951, Estimated use of water in the United States-1950: U.S. Geological Survey Circular 115, $13 \mathrm{p}$.

MacKichan, K.A., and Kammerer, J.C., 1957, Estimated use of water in the United States, 1955:

U.S. Geological Survey Circular 398, 18 p.

1961, Estimated use of water in the United States in 1960: U.S. Geological Survey Circular 456, 44 p.

Maryland Department of Agriculture, 1988, Aquaculture in Maryland: Information Sheet, Annapolis, Maryland, $2 \mathrm{p}$.

Maryland Department of State Planning, 1981, Maryland population data--state, county, minor civil division and municipal trends through 1980: Maryland Department of State Planning, Office of Planning Data, Baltimore, 253 p.

1987, Department of State Planning population projections: Maryland Department of State Planning, Office of Planning Data, Report 1A-Total (Revisions, September 1987), Baltimore, 50 p.

Maryland Water Resources Administration, 1987, Maryland water withdrawal and use report for 1985: Maryland Department of Natural Resources, Annapolis, Maryland, 40 p.

Murray, C.R., 1968, Estimated use of water in the United States in 1965: U.S. Geological Survey Circular 556, $53 \mathrm{p}$.

Murray, C.R., and Reeves, E.B., 1972, Estimated use of water in the United States in 1970: U.S. Geological Survey Circular 675, $37 \mathrm{p}$.

1977, Estimated use of water in the United States in 1975: U.S. Geological Survey Circular 765, 39 p.

Solley, W.B., Chase, E.B., and Mann, W.B., 1983, Estimated use of water in the United States in 1980:

U.S. Geological Survey Circular 1001, 82 p.

Solley, W.B., Merk, C.F., and Pierce, R.R., 1988, Estimated use of water in the United States in 1985:

U.S. Geological Survey Circular 1004, 82 p. 
U.S. Department of Commerce, 1988, 1987 census of agriculture, advance county reports: U.S. Bureau of the Census, Government Printing Office, Washington, D.C., 23 2-page county sheets.

U.S. Environmental Protection Agency, 1973, Manual of individual water supply systems: U.S. Government Printing Office, Washington, D.C., 155 p.

U.S. Geological Survey, 1990, National water summary 1987--hydrologic events and water supply and use: U.S. Geological Survey Water-Supply Paper 2350, 553 p.

Weisberg, S.B., and Rose, K.A., 1985, Inventory of Maryland dams and assessment of hydropower resources: Columbia, Maryland, Martin Marietta Environmental Systems, 341 p. 
APPENDIX

Water-withdrawal and use data 
के

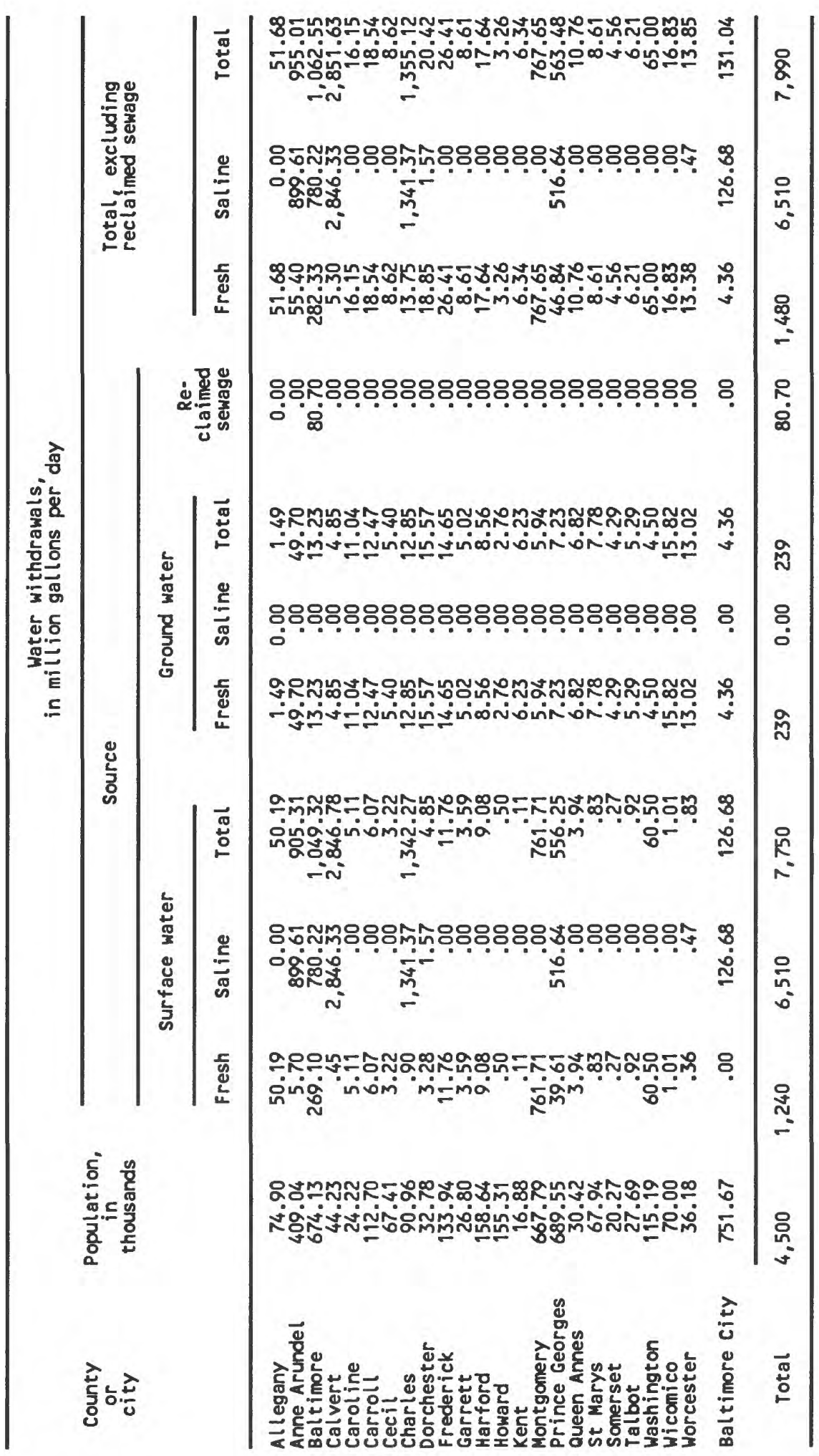




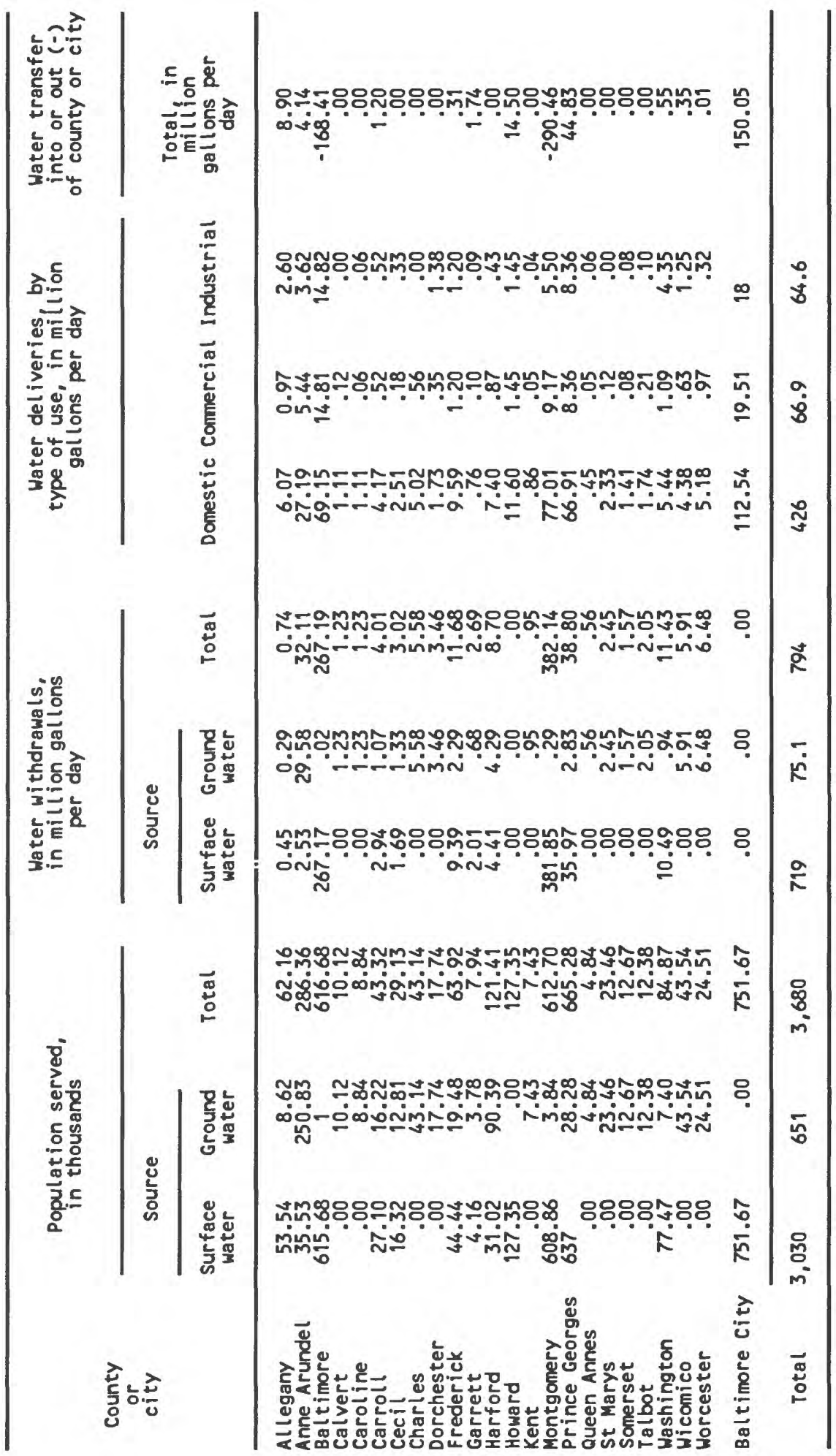


Table 4.--Domestic water withdrawals (self-supplied) and deliveries from public suppliers in Maryland, by county, 1987

[Total amounts at bottom of table are rounded to three significant figures]

\begin{tabular}{|c|c|c|c|c|c|c|c|}
\hline \multirow{4}{*}{$\begin{array}{l}\text { County } \\
\text { or } \\
\text { city }\end{array}$} & \multicolumn{4}{|c|}{ Self-supplied } & \multicolumn{2}{|c|}{ Public-supplied } & \multirow{4}{*}{$\begin{array}{c}\text { Total } \\
\begin{array}{c}\text { With- } \\
\text { drawals } \\
\text { and }\end{array} \\
\text { deliveries, } \\
\text { in million } \\
\text { gallons } \\
\text { per day }\end{array}$} \\
\hline & \multirow{3}{*}{$\begin{array}{l}\text { Population } \\
\text { (self- } \\
\text { supplied), } \\
\text { in thousands }\end{array}$} & \multicolumn{3}{|c|}{$\begin{array}{l}\text { Water withdrawals, in } \\
\text { million gallons per day }\end{array}$} & \multirow{3}{*}{$\begin{array}{l}\text { Population } \\
\text { served, in } \\
\text { thousands }\end{array}$} & \multirow{3}{*}{$\begin{array}{c}\text { Water } \\
\text { deliveries, } \\
\text { in million } \\
\text { gallons } \\
\text { per day }\end{array}$} & \\
\hline & & \multicolumn{2}{|c|}{ Source } & \multirow[b]{2}{*}{ Total } & & & \\
\hline & & $\begin{array}{l}\text { Surface } \\
\text { water }\end{array}$ & $\begin{array}{r}\text { Ground } \\
\text { water }\end{array}$ & & & & \\
\hline $\begin{array}{l}\text { Allegany } \\
\text { Anne Arundel } \\
\text { Baltimore } \\
\text { Calvert } \\
\text { Caroline } \\
\text { Carroll } \\
\text { Cecil } \\
\text { Charles } \\
\text { Dorchester } \\
\text { Frederick } \\
\text { Garrett } \\
\text { Harford } \\
\text { Howard } \\
\text { Kent } \\
\text { Montgomery } \\
\text { Prince Georges } \\
\text { Queen Annes } \\
\text { St Marys } \\
\text { Somerset } \\
\text { Talbot } \\
\text { Washington } \\
\text { Wicomico } \\
\text { Worcester }\end{array}$ & $\begin{array}{r}12.74 \\
122.68 \\
57.45 \\
34.11 \\
15.38 \\
69.38 \\
38.28 \\
47.82 \\
15.04 \\
70.02 \\
18.86 \\
37.23 \\
27.96 \\
9.45 \\
55.09 \\
24.27 \\
25.58 \\
44.48 \\
7.60 \\
15.31 \\
30.32 \\
26.46 \\
11.67\end{array}$ & $\begin{array}{l}0.00 \\
.00 \\
.00 \\
.00 \\
.00 \\
.00 \\
.00 \\
.00 \\
.00 \\
.00 \\
.00 \\
.00 \\
.00 \\
.00 \\
.00 \\
.00 \\
.00 \\
.00 \\
.00 \\
.00 \\
.00 \\
.00 \\
.00\end{array}$ & $\begin{array}{r}1.00 \\
10.45 \\
4.63 \\
2.79 \\
1.28 \\
5.59 \\
3.07 \\
3.83 \\
1.20 \\
5.65 \\
1.51 \\
2.98 \\
2.28 \\
.76 \\
4.69 \\
1.96 \\
2.05 \\
3.62 \\
.61 \\
1.31 \\
2.45 \\
2.48 \\
1.08\end{array}$ & $\begin{array}{r}1.00 \\
10.45 \\
4.63 \\
2.79 \\
1.28 \\
5.59 \\
3.07 \\
3.83 \\
1.20 \\
5.65 \\
1.51 \\
2.98 \\
2.28 \\
.76 \\
4.69 \\
1.96 \\
2.05 \\
3.62 \\
.61 \\
1.31 \\
2.45 \\
2.48 \\
1.08\end{array}$ & $\begin{array}{r}62.16 \\
286.36 \\
616.68 \\
10.12 \\
8.84 \\
43.32 \\
29.13 \\
43.14 \\
17.74 \\
63.92 \\
7.94 \\
121.41 \\
127.35 \\
7.43 \\
612.70 \\
665.28 \\
4.84 \\
23.46 \\
12.67 \\
12.38 \\
84.87 \\
43.54 \\
24.51\end{array}$ & $\begin{array}{r}6.07 \\
27.19 \\
69.15 \\
1.11 \\
1.11 \\
4.17 \\
2.51 \\
5.02 \\
1.73 \\
9.59 \\
.76 \\
7.40 \\
11.60 \\
.86 \\
77.01 \\
66.91 \\
.45 \\
2.33 \\
1.41 \\
1.74 \\
5.44 \\
4.38 \\
5.18\end{array}$ & $\begin{array}{r}7.07 \\
37.64 \\
73.78 \\
3.90 \\
2.39 \\
9.76 \\
5.58 \\
8.85 \\
2.93 \\
15.24 \\
2.27 \\
10.38 \\
13.88 \\
1.62 \\
81.70 \\
68.87 \\
2.50 \\
5.95 \\
2.02 \\
3.05 \\
7.89 \\
6.86 \\
6.26\end{array}$ \\
\hline Baltimore City & .00 & .00 & .00 & .00 & 751.67 & 112.54 & 112.54 \\
\hline Total & 817 & 0.00 & 67.3 & 67.3 & 3,680 & 426 & 493 \\
\hline
\end{tabular}


Table 5.-Commercial freshwater withdrawals (self-supplied) and deliveries from public suppliers in Maryland, by county, 1987

[Total amounts at bottom of table are rounded to three significant figures]

\begin{tabular}{|c|c|c|c|c|c|}
\hline \multirow{3}{*}{$\begin{array}{l}\text { County } \\
\text { or } \\
\text { city }\end{array}$} & \multicolumn{3}{|c|}{ Self-supplied } & \multirow{3}{*}{$\begin{array}{l}\text { Public-supplied } \\
\\
\text { Water deliveries, } \\
\text { in million } \\
\text { gallons per day }\end{array}$} & \multirow{3}{*}{$\begin{array}{l}\text { Withdrawals anc } \\
\text { deliveries, } \\
\text { in million } \\
\text { gallons per day }\end{array}$} \\
\hline & $\begin{array}{l}\text { Water with } \\
\text { million } 88\end{array}$ & $\begin{array}{l}\text { lrawals, } \\
\text { lons per }\end{array}$ & $\begin{array}{l}n \\
\text { day }\end{array}$ & & \\
\hline & $\begin{array}{c}\text { Surface } \\
\text { water }\end{array}$ & $\begin{array}{r}\text { Ground } \\
\text { water }\end{array}$ & Total & & \\
\hline $\begin{array}{l}\text { Allegany } \\
\text { Anne Arundel } \\
\text { Baltimore } \\
\text { Calvert } \\
\text { Caroline } \\
\text { Carroll } \\
\text { Cecil } \\
\text { Charles } \\
\text { Dorchester } \\
\text { Frederick } \\
\text { Garrett } \\
\text { Harford } \\
\text { Howard } \\
\text { Kent } \\
\text { Montgomery } \\
\text { Prince Georges } \\
\text { Queen Annes } \\
\text { St Marys } \\
\text { Somerset } \\
\text { Talbot } \\
\text { Washington } \\
\text { Wicomico } \\
\text { Worcester }\end{array}$ & $\begin{array}{l}0.02 \\
.32 \\
.06 \\
.02 \\
.00 \\
.44 \\
.23 \\
.00 \\
.00 \\
.04 \\
.32 \\
3.95 \\
.06 \\
.00 \\
.00 \\
.01 \\
.00 \\
.00 \\
.00 \\
.00 \\
.06 \\
.00 \\
.00\end{array}$ & $\begin{array}{r}0.16 \\
6.31 \\
.59 \\
.41 \\
.22 \\
.47 \\
.48 \\
1.90 \\
.13 \\
.91 \\
.41 \\
.46 \\
.33 \\
.13 \\
.40 \\
1.48 \\
.43 \\
1.54 \\
.21 \\
.29 \\
.11 \\
.47 \\
.40\end{array}$ & $\begin{array}{r}0.18 \\
6.63 \\
.65 \\
.43 \\
.22 \\
.91 \\
.71 \\
1.90 \\
.13 \\
.95 \\
.73 \\
4.41 \\
.39 \\
.13 \\
.40 \\
1.49 \\
.43 \\
1.54 \\
.21 \\
.29 \\
.17 \\
.47 \\
.40\end{array}$ & $\begin{array}{r}0.97 \\
5.44 \\
14.81 \\
.12 \\
.06 \\
.52 \\
.18 \\
.56 \\
.35 \\
1.20 \\
.10 \\
.87 \\
1.45 \\
.05 \\
9.17 \\
8.36 \\
.05 \\
.12 \\
.08 \\
.21 \\
1.09 \\
.63 \\
.97\end{array}$ & $\begin{array}{r}1.15 \\
12.07 \\
15.46 \\
.55 \\
.28 \\
1.43 \\
.89 \\
2.46 \\
.48 \\
2.15 \\
.83 \\
5.28 \\
1.84 \\
.18 \\
9.57 \\
9.85 \\
.48 \\
1.66 \\
.29 \\
.50 \\
1.26 \\
1.10 \\
1.37\end{array}$ \\
\hline Baltimore City & .00 & .00 & .00 & 19.51 & 19.51 \\
\hline Total & 5.53 & 18.2 & 23.8 & 66.9 & 90.6 \\
\hline
\end{tabular}


Table 6.--Industrial water withdrawals (self-supplied) and deliveries from public suppliers in Maryland, by county, 1987

[Total amounts at bottom of table are rounded to three significant figures]

\begin{tabular}{|c|c|c|c|c|c|c|c|c|c|c|}
\hline \multirow{3}{*}{$\begin{array}{c}\text { County } \\
\text { or } \\
\text { city }\end{array}$} & \multicolumn{8}{|c|}{ Self-supplied withdrawals, in million gallons per day } & \multirow{3}{*}{$\begin{array}{c}\text { Public- } \\
\text { supplied } \\
\text { deliveries } \\
\text { of } \\
\text { freshwater, } \\
\text { in million } \\
\text { gallons } \\
\text { per day }\end{array}$} & \multirow{3}{*}{$\begin{array}{c}\text { Total } \\
\text { withdrawals } \\
\text { and } \\
\text { deliveries of } \\
\text { freshwater, } \\
\text { in million } \\
\text { gallons } \\
\text { per day }\end{array}$} \\
\hline & \multicolumn{5}{|c|}{ Source } & \multicolumn{3}{|c|}{$\begin{array}{l}\text { Total, excluding } \\
\text { reclaimed sewage }\end{array}$} & & \\
\hline & Fresh & Saline & Fresh & Saline & $\begin{array}{c}\text { Re- } \\
\text { claimed } \\
\text { sewage }\end{array}$ & Fresh & Saline & Total & & \\
\hline $\begin{array}{l}\text { Allegany } \\
\text { Anne Arundel } \\
\text { Baltimore } \\
\text { Calvert } \\
\text { Caroline } \\
\text { Carroll } \\
\text { Cecil } \\
\text { Charles } \\
\text { Dorchester } \\
\text { Frederick } \\
\text { Garrett } \\
\text { Harford } \\
\text { Howard } \\
\text { Kent } \\
\text { Montgomery } \\
\text { Prince Georges } \\
\text { Queen Anne } \\
\text { St Marys } \\
\text { Somerset } \\
\text { Talbot } \\
\text { Washington } \\
\text { Wicomico } \\
\text { Worcester }\end{array}$ & $\begin{array}{r}49.28 \\
.00 \\
.28 \\
.00 \\
.00 \\
2.01 \\
.55 \\
.01 \\
.00 \\
.00 \\
.35 \\
.03 \\
.24 \\
.00 \\
.02 \\
.00 \\
.01 \\
.01 \\
.00 \\
.00 \\
2.96 \\
.00 \\
.00\end{array}$ & $\begin{array}{r}0.00 \\
.01 \\
273.38 \\
.00 \\
.00 \\
.00 \\
.00 \\
.00 \\
.40 \\
.00 \\
.00 \\
.00 \\
.00 \\
.00 \\
.00 \\
.00 \\
.00 \\
.00 \\
.00 \\
.00 \\
.00 \\
.00 \\
.00\end{array}$ & $\begin{array}{l}0.02 \\
3.16 \\
4.20 \\
.02 \\
.45 \\
.06 \\
.04 \\
.00 \\
.92 \\
.28 \\
.03 \\
.16 \\
.04 \\
.37 \\
.03 \\
.02 \\
.27 \\
.04 \\
.11 \\
.58 \\
.01 \\
2.99 \\
1.76\end{array}$ & $\begin{array}{l}0.00 \\
.00 \\
.00 \\
.00 \\
.00 \\
.00 \\
.00 \\
.00 \\
.00 \\
.00 \\
.00 \\
.00 \\
.00 \\
.00 \\
.00 \\
.00 \\
.00 \\
.00 \\
.00 \\
.00 \\
.00 \\
.00 \\
.00\end{array}$ & $\begin{array}{r}0.00 \\
.00 \\
80.70 \\
.00 \\
.00 \\
.00 \\
.00 \\
.00 \\
.00 \\
.00 \\
.00 \\
.00 \\
.00 \\
.00 \\
.00 \\
.00 \\
.00 \\
.00 \\
.00 \\
.00 \\
.00 \\
.00 \\
.00\end{array}$ & $\begin{array}{r}49.30 \\
3.16 \\
4.48 \\
.02 \\
.45 \\
2.07 \\
.59 \\
.01 \\
.92 \\
.28 \\
.38 \\
.19 \\
.28 \\
.37 \\
.05 \\
.02 \\
.28 \\
.05 \\
.11 \\
.58 \\
2.97 \\
2.99 \\
1.76\end{array}$ & $\begin{array}{r}0.00 \\
.01 \\
273.38 \\
.00 \\
.00 \\
.00 \\
.00 \\
.00 \\
.40 \\
.00 \\
.00 \\
.00 \\
.00 \\
.00 \\
.00 \\
.00 \\
.00 \\
.00 \\
.00 \\
.00 \\
.00 \\
.00 \\
.00\end{array}$ & $\begin{array}{r}49.30 \\
3.17 \\
277.86 \\
.02 \\
.45 \\
2.07 \\
.59 \\
.01 \\
1.32 \\
.28 \\
.38 \\
.19 \\
.28 \\
.37 \\
.05 \\
.02 \\
.28 \\
.05 \\
.11 \\
.58 \\
2.97 \\
2.99 \\
1.76\end{array}$ & $\begin{array}{r}2.60 \\
3.62 \\
14.82 \\
.00 \\
.06 \\
.52 \\
.33 \\
.00 \\
1.38 \\
1.20 \\
.09 \\
.43 \\
1.45 \\
.04 \\
5.50 \\
8.36 \\
.06 \\
.00 \\
.08 \\
.10 \\
4.35 \\
1.25 \\
.32\end{array}$ & $\begin{array}{r}51.90 \\
6.78 \\
19.30 \\
.02 \\
.51 \\
2.59 \\
.92 \\
.01 \\
2.30 \\
1.48 \\
.47 \\
.62 \\
1.73 \\
.41 \\
5.55 \\
8.38 \\
.34 \\
.05 \\
.19 \\
.68 \\
7.32 \\
4.24 \\
2.08\end{array}$ \\
\hline Baltimore City & .00 & 13.29 & 4.36 & .00 & .00 & 4.36 & 13.29 & 17.65 & 18.00 & 22.36 \\
\hline Total & 55.8 & 287 & 19.9 & 0.00 & 80.7 & 75.7 & 287 & 363 & 64.6 & 140 \\
\hline
\end{tabular}


Table 7.-Mining water withdrawals in Maryland, by county, 1987

[Total amounts at bottom of table are rounded to three significant figures]

\begin{tabular}{|c|c|c|c|c|c|c|c|c|c|}
\hline \multirow{4}{*}{$\begin{array}{c}\text { County } \\
\text { or } \\
\text { city }\end{array}$} & \multirow{2}{*}{\multicolumn{6}{|c|}{ Water withdrawals, in million gallons per }} & & & \\
\hline & & & & & & & \multicolumn{3}{|c|}{ Total } \\
\hline & \multicolumn{2}{|c|}{ Surface water } & \multirow{2}{*}{ Total } & \multicolumn{2}{|c|}{ Ground water } & \multirow{2}{*}{ Total } & \multirow[b]{2}{*}{ Fresh } & \multirow[b]{2}{*}{ Saline } & \multirow[b]{2}{*}{ Total } \\
\hline & Fresh & Saline & & Fresh & Saline & & & & \\
\hline $\begin{array}{l}\text { Allegany } \\
\text { Anne Arundel } \\
\text { Baltimore } \\
\text { Calvert } \\
\text { Caroline } \\
\text { Carroll } \\
\text { Cecil } \\
\text { Charles } \\
\text { Dorchester } \\
\text { Frederick } \\
\text { Garrett } \\
\text { Harford } \\
\text { Howard } \\
\text { Kent } \\
\text { Montgomery } \\
\text { Prince Georges } \\
\text { Queen Annes } \\
\text { St Marys } \\
\text { Somerset } \\
\text { Talbot } \\
\text { Washington } \\
\text { Wicomico } \\
\text { Worcester }\end{array}$ & $\begin{array}{l}0.02 \\
2.23 \\
.63 \\
.00 \\
.00 \\
.00 \\
.42 \\
.11 \\
.89 \\
.04 \\
.41 \\
.03 \\
.00 \\
.00 \\
.10 \\
3.10 \\
.00 \\
.25 \\
.00 \\
.00 \\
.00 \\
.00 \\
.00\end{array}$ & $\begin{array}{r}0.00 \\
14.00 \\
.00 \\
.00 \\
.00 \\
.00 \\
.00 \\
.00 \\
.00 \\
.00 \\
.00 \\
.00 \\
.00 \\
.00 \\
.00 \\
.00 \\
.00 \\
.00 \\
.00 \\
.00 \\
.00 \\
.47\end{array}$ & $\begin{array}{r}0.02 \\
2.23 \\
15.41 \\
.00 \\
.00 \\
.00 \\
.42 \\
.11 \\
.89 \\
.04 \\
.41 \\
.03 \\
.00 \\
.00 \\
.10 \\
3.10 \\
.00 \\
.25 \\
.00 \\
.00 \\
.00 \\
.00 \\
.47\end{array}$ & $\begin{array}{l}0.00 \\
.06 \\
3.46 \\
.00 \\
.00 \\
4.76 \\
.18 \\
.91 \\
.00 \\
4.10 \\
2.15 \\
.33 \\
.00 \\
.00 \\
.20 \\
.07 \\
.00 \\
.03 \\
.00 \\
.00 \\
.26 \\
.01 \\
.01\end{array}$ & $\begin{array}{l}0.00 \\
.00 \\
.00 \\
.00 \\
.00 \\
.00 \\
.00 \\
.00 \\
.00 \\
.00 \\
.00 \\
.00 \\
.00 \\
.00 \\
.00 \\
.00 \\
.00 \\
.00 \\
.00 \\
.00 \\
.00 \\
.00 \\
.00\end{array}$ & $\begin{array}{l}0.00 \\
.06 \\
3.46 \\
.00 \\
.00 \\
4.76 \\
.18 \\
.91 \\
.00 \\
4.10 \\
2.15 \\
.33 \\
.00 \\
.00 \\
.20 \\
.07 \\
.00 \\
.03 \\
.00 \\
.00 \\
.26 \\
.01 \\
.01\end{array}$ & $\begin{array}{r}0.02 \\
2.29 \\
4.09 \\
.00 \\
.00 \\
4.76 \\
.60 \\
1.02 \\
.89 \\
4.14 \\
2.56 \\
.36 \\
.00 \\
.00 \\
.30 \\
3.17 \\
.00 \\
.28 \\
.00 \\
.00 \\
.26 \\
.01 \\
.01\end{array}$ & $\begin{array}{r}0.00 \\
14.00 \\
.00 \\
.00 \\
.00 \\
.00 \\
.00 \\
.00 \\
.00 \\
.00 \\
.00 \\
.00 \\
.00 \\
.00 \\
.00 \\
.00 \\
.00 \\
.00 \\
.00 \\
.00 \\
.00 \\
.47\end{array}$ & $\begin{array}{r}0.02 \\
2.29 \\
18.87 \\
.00 \\
.00 \\
4.76 \\
.60 \\
1.02 \\
.89 \\
4.14 \\
2.56 \\
.36 \\
.00 \\
.00 \\
.30 \\
3.17 \\
.00 \\
.28 \\
.00 \\
.00 \\
.26 \\
.01 \\
.48\end{array}$ \\
\hline Baltimore City & .00 & .01 & .01 & .00 & .00 & .00 & .00 & .01 & .01 \\
\hline Total & 8.23 & 15.3 & 23.5 & 16.5 & 0.00 & 16.5 & 24.8 & 15.3 & 40.0 \\
\hline
\end{tabular}


Table 8.--Thermoelectric power generation water withdrawals in Maryland, by county, 1987

[Total amounts at bottom of table are rounded to three significant figures]

\begin{tabular}{|c|c|c|c|c|c|}
\hline \multirow{3}{*}{$\begin{array}{l}\text { County } \\
\text { or } \\
\text { city }\end{array}$} & \multicolumn{5}{|c|}{ Water withdrawals, in million gallons per day } \\
\hline & \multicolumn{4}{|c|}{ Source } & \multirow{2}{*}{$\begin{array}{c}\text { Total } \\
\text { freshwater } \\
\text { withdrawals }\end{array}$} \\
\hline & Fresh & Saline & Total & $\begin{array}{l}\text { Fresh } \\
\text { ground } \\
\text { water }\end{array}$ & \\
\hline $\begin{array}{l}\text { Allegany } \\
\text { Anne Arundel } \\
\text { Baltimore } \\
\text { Calvert } \\
\text { Caroline } \\
\text { Carroll } \\
\text { Cecil } \\
\text { Charles } \\
\text { Dorchester } \\
\text { Frederick } \\
\text { Garrett } \\
\text { Harford } \\
\text { Howard } \\
\text { Kent } \\
\text { Montgomery } \\
\text { Prince Georges } \\
\text { Queen Annes } \\
\text { St Marys } \\
\text { Somerset } \\
\text { Talbot } \\
\text { Washington } \\
\text { Wicomico } \\
\text { Worcester }\end{array}$ & $\begin{array}{r}0.00 \\
.00 \\
.00 \\
.00 \\
.00 \\
.00 \\
.00 \\
.00 \\
.00 \\
.00 \\
.00 \\
.00 \\
.00 \\
.00 \\
379.04 \\
.00 \\
.00 \\
.00 \\
.00 \\
.00 \\
46.64 \\
.00 \\
.00\end{array}$ & $\begin{array}{r}0.00 \\
899.60 \\
492.06 \\
2846.33 \\
.00 \\
.00 \\
.00 \\
1341.37 \\
1.17 \\
.00 \\
.00 \\
.00 \\
.00 \\
.00 \\
.00 \\
516.64 \\
.00 \\
.00 \\
.00 \\
.00 \\
.00 \\
.00 \\
.00\end{array}$ & $\begin{array}{r}0.00 \\
899.60 \\
492.06 \\
2846.33 \\
.00 \\
.00 \\
.00 \\
1341.37 \\
1.17 \\
.00 \\
.00 \\
.00 \\
.00 \\
.00 \\
379.04 \\
516.04 \\
.00 \\
.00 \\
.00 \\
.00 \\
46.64 \\
.00 \\
.00\end{array}$ & $\begin{array}{l}0.00 \\
.00 \\
.00 \\
.32 \\
.00 \\
.00 \\
.00 \\
.52 \\
.03 \\
.00 \\
.00 \\
.00 \\
.00 \\
.00 \\
.00 \\
.73 \\
.00 \\
.00 \\
.00 \\
.00 \\
.00 \\
.00 \\
.00\end{array}$ & $\begin{array}{r}0.00 \\
.00 \\
.00 \\
.32 \\
.00 \\
.00 \\
.00 \\
.52 \\
.03 \\
.00 \\
.00 \\
.00 \\
.00 \\
.00 \\
379.04 \\
.73 \\
.00 \\
.00 \\
.00 \\
.00 \\
46.64 \\
.00 \\
.00\end{array}$ \\
\hline Baltimore City & .00 & 113.38 & 113.38 & .00 & .00 \\
\hline Total & 426 & 6,210 & 6,640 & 1.60 & 427 \\
\hline
\end{tabular}


Table 9.--Hydroelectric power generation water use in Maryland, by county, 1987

[Total amounts at bottom of table are rounded to three significant figures]

\begin{tabular}{|c|c|c|}
\hline \multirow{2}{*}{$\begin{array}{c}\text { County } \\
\text { or } \\
\text { city }\end{array}$} & \multicolumn{2}{|c|}{ Water use } \\
\hline & $\begin{array}{l}\text { Million } \\
\text { gallons } \\
\text { per day }\end{array}$ & $\begin{array}{l}\text { Thousand } \\
\text { acre-feet } \\
\text { per year }\end{array}$ \\
\hline $\begin{array}{l}\text { Allegany } \\
\text { Anne Arundel } \\
\text { Baltimore } \\
\text { Calvert } \\
\text { Caroline } \\
\text { Carroll } \\
\text { Cecil } \\
\text { Charles } \\
\text { Dorchester } \\
\text { Frederick } \\
\text { Garrett } \\
\text { Harford } \\
\text { Howard } \\
\text { Kent } \\
\text { Montgomery } \\
\text { Prince Georges } \\
\text { Queen Annes } \\
\text { St Marys } \\
\text { Somerset } \\
\text { Talbot } \\
\text { Washington } \\
\text { Wicomico } \\
\text { Worcester }\end{array}$ & $\begin{array}{r}0.00 \\
.00 \\
.00 \\
.00 \\
.00 \\
.00 \\
7.73 \\
.00 \\
.00 \\
.00 \\
60.84 \\
17,950.68 \\
.00 \\
.00 \\
.00 \\
.00 \\
.00 \\
.00 \\
.00 \\
.00 \\
1228.53 \\
.00 \\
.00\end{array}$ & $\begin{array}{r}0.00 \\
.00 \\
.00 \\
.00 \\
.00 \\
.00 \\
8.67 \\
.00 \\
.00 \\
.00 \\
68.20 \\
20,122.71 \\
.00 \\
.00 \\
.00 \\
.00 \\
.00 \\
.00 \\
.00 \\
.00 \\
1377.18 \\
.00 \\
.00\end{array}$ \\
\hline Baltimore City & .00 & .00 \\
\hline Total & 19,200 & 21,600 \\
\hline
\end{tabular}


Table 10.-Agricultural (nonirrigation) water withdrawals in Maryland, by county, 1987

[Total amounts at bottom of table are rounded to three significant figures]

\begin{tabular}{|c|c|c|c|}
\hline \multirow{3}{*}{$\begin{array}{c}\text { County } \\
\text { or } \\
\text { city }\end{array}$} & \multicolumn{3}{|c|}{$\begin{array}{l}\text { Water withdrawals, in } \\
\text { million gallons per day }\end{array}$} \\
\hline & \multicolumn{2}{|c|}{ Source } & \multirow{2}{*}{ Total } \\
\hline & Surface water & Ground water & \\
\hline $\begin{array}{l}\text { Allegany } \\
\text { Anne Arundel } \\
\text { Baltimore } \\
\text { Calvert } \\
\text { Caroline } \\
\text { Carroll } \\
\text { Cecil } \\
\text { Charles } \\
\text { Dorchester } \\
\text { Frederick } \\
\text { Garrett } \\
\text { Harford } \\
\text { Howard } \\
\text { Kent } \\
\text { Montgomery } \\
\text { Prince Georges } \\
\text { Queen Annes } \\
\text { St Marys } \\
\text { Somerset } \\
\text { Talbot } \\
\text { Washington } \\
\text { Wicomico } \\
\text { Worcester }\end{array}$ & $\begin{array}{l}0.06 \\
.04 \\
.13 \\
.02 \\
.04 \\
.31 \\
.10 \\
.04 \\
.01 \\
.48 \\
.22 \\
.17 \\
.10 \\
.06 \\
.11 \\
.04 \\
.06 \\
.05 \\
.02 \\
.03 \\
.31 \\
.02 \\
.03\end{array}$ & $\begin{array}{r}0.02 \\
.03 \\
.16 \\
.00 \\
.28 \\
.46 \\
.20 \\
.04 \\
.19 \\
1.40 \\
.24 \\
.21 \\
.08 \\
.21 \\
.14 \\
.02 \\
.22 \\
.08 \\
.79 \\
.18 \\
.71 \\
1.15 \\
1.15\end{array}$ & $\begin{array}{r}0.08 \\
.07 \\
.29 \\
.02 \\
.32 \\
.77 \\
.30 \\
.08 \\
.20 \\
1.88 \\
.46 \\
.38 \\
.18 \\
.27 \\
.25 \\
.06 \\
.28 \\
.13 \\
.81 \\
.21 \\
1.02 \\
1.17 \\
1.18\end{array}$ \\
\hline Baltimore City & .00 & .00 & .00 \\
\hline Total & 2.45 & 7.96 & 10.4 \\
\hline
\end{tabular}


Table 11.--Irrigation water withdrawals in Maryland, by county, 1987

[Total amounts at bottom of table are rounded to three significant figures]

\begin{tabular}{|c|c|c|c|c|c|c|c|c|}
\hline \multirow{4}{*}{$\begin{array}{l}\text { County } \\
\text { or } \\
\text { city }\end{array}$} & & & \multicolumn{6}{|c|}{ Water withdrawals } \\
\hline & \multirow{2}{*}{\multicolumn{2}{|c|}{$\begin{array}{l}\text { Irrigated land } \\
\text { by type, in } \\
\text { thousand acres }\end{array}$}} & \multicolumn{3}{|c|}{ Thousand acre-feet per year } & \multicolumn{3}{|c|}{ Million gallons per day } \\
\hline & & & \multicolumn{2}{|c|}{ Source } & \multirow{2}{*}{ Total } & \multicolumn{2}{|c|}{ Source } & \multirow{2}{*}{ Total } \\
\hline & Spray & Flood & Surface & Ground & & Surface & Ground & \\
\hline $\begin{array}{l}\text { Allegany } \\
\text { Anne Arunde1 } \\
\text { Baltimore } \\
\text { Calvert } \\
\text { Caroline } \\
\text { Carroll } \\
\text { Cecil } \\
\text { Charles } \\
\text { Dorchester } \\
\text { Frederick } \\
\text { Garrett } \\
\text { Harford } \\
\text { Howard } \\
\text { Kent } \\
\text { Montgomery } \\
\text { Prince Georges } \\
\text { Queen Annes } \\
\text { St Marys } \\
\text { Somerset } \\
\text { Talbot } \\
\text { Washington } \\
\text { Wicomico } \\
\text { Worcester }\end{array}$ & $\begin{array}{r}0.12 \\
.15 \\
.93 \\
.56 \\
18.63 \\
.51 \\
.32 \\
.98 \\
15.59 \\
.28 \\
.30 \\
.75 \\
.16 \\
2.50 \\
.39 \\
.33 \\
9.62 \\
.84 \\
1.58 \\
1.86 \\
.07 \\
5.26 \\
2.47\end{array}$ & $\begin{array}{l}0.00 \\
.00 \\
.00 \\
.00 \\
.00 \\
.00 \\
.00 \\
.00 \\
.00 \\
.00 \\
.00 \\
.00 \\
.00 \\
.00 \\
.00 \\
.00 \\
.00 \\
.00 \\
.00 \\
.00 \\
.00 \\
.00 \\
.00\end{array}$ & $\begin{array}{r}0.40 \\
.65 \\
.93 \\
.46 \\
5.68 \\
.41 \\
.26 \\
.83 \\
2.67 \\
.31 \\
.31 \\
.55 \\
.11 \\
.06 \\
.66 \\
.55 \\
4.34 \\
.58 \\
.28 \\
1.00 \\
.04 \\
1.11 \\
.37\end{array}$ & $\begin{array}{r}0.00 \\
.12 \\
.19 \\
.09 \\
8.50 \\
.07 \\
.11 \\
.08 \\
10.81 \\
.02 \\
.00 \\
.15 \\
.03 \\
4.27 \\
.21 \\
.13 \\
3.69 \\
.02 \\
1.12 \\
.99 \\
.02 \\
3.15 \\
2.40\end{array}$ & $\begin{array}{r}0.40 \\
.77 \\
1.12 \\
.55 \\
14.18 \\
.48 \\
.37 \\
.91 \\
13.47 \\
.34 \\
.31 \\
.70 \\
.15 \\
4.33 \\
.87 \\
.68 \\
8.03 \\
.61 \\
1.40 \\
1.98 \\
.07 \\
4.26 \\
2.77\end{array}$ & $\begin{array}{r}0.36 \\
.58 \\
.83 \\
.41 \\
5.07 \\
.37 \\
.23 \\
.74 \\
2.38 \\
.28 \\
.28 \\
.49 \\
.10 \\
.05 \\
.59 \\
.49 \\
3.87 \\
.52 \\
.25 \\
.89 \\
.04 \\
.99 \\
.33\end{array}$ & $\begin{array}{r}0.00 \\
.11 \\
.17 \\
.08 \\
7.58 \\
.06 \\
.10 \\
.07 \\
9.64 \\
.02 \\
.00 \\
.13 \\
.03 \\
3.81 \\
.19 \\
.12 \\
3.29 \\
.02 \\
1.00 \\
.88 \\
.02 \\
2.81 \\
2.14\end{array}$ & $\begin{array}{r}0.36 \\
.69 \\
1.00 \\
.49 \\
12.65 \\
.43 \\
.33 \\
.81 \\
12.02 \\
.30 \\
.28 \\
.62 \\
.13 \\
3.86 \\
.78 \\
.61 \\
7.16 \\
.54 \\
1.25 \\
1.77 \\
.06 \\
3.80 \\
2.47\end{array}$ \\
\hline Baltimore City & .00 & .00 & .00 & .00 & .00 & .00 & .00 & .00 \\
\hline Total & 64.2 & 0.00 & 22.6 & 36.2 & 58.8 & 20.1 & 32.3 & 52.4 \\
\hline
\end{tabular}


Table 12.--Aquaculture water withdrawals in Maryland, by county, 1987

[Total amounts at bottom of table are rounded to three significant figures]

\begin{tabular}{|c|c|c|c|c|c|}
\hline \multirow{4}{*}{$\begin{array}{l}\text { County } \\
\text { or } \\
\text { city }\end{array}$} & \multicolumn{5}{|c|}{ Water withdrawals, in million gallons per day } \\
\hline & \multicolumn{4}{|c|}{ Source } & \multirow{3}{*}{$\begin{array}{c}\text { Total } \\
\text { freshwater } \\
\text { withdrawals }\end{array}$} \\
\hline & \multicolumn{3}{|c|}{ Surface water } & \multirow{2}{*}{$\begin{array}{c}\text { Fresh } \\
\text { ground } \\
\text { water }\end{array}$} & \\
\hline & Fresh & Saline & Total & & \\
\hline $\begin{array}{l}\text { Allegany } \\
\text { Anne Arunde1 } \\
\text { Baltimore } \\
\text { Calvert } \\
\text { Caroline } \\
\text { Carroll } \\
\text { Cecil } \\
\text { Charles } \\
\text { Dorchester } \\
\text { Frederick } \\
\text { Garrett } \\
\text { Barford } \\
\text { Boward } \\
\text { Kent } \\
\text { Montgomery } \\
\text { Prince Georges } \\
\text { Queen Annes } \\
\text { St Marys } \\
\text { Somerset } \\
\text { Talbot } \\
\text { Washington } \\
\text { Wicomico } \\
\text { Horcester }\end{array}$ & $\begin{array}{l}0.01 \\
.00 \\
.00 \\
.00 \\
.00 \\
.00 \\
.00 \\
.00 \\
.00 \\
1.53 \\
.30 \\
.00 \\
.00 \\
.00 \\
.00 \\
.00 \\
.00 \\
.00 \\
.00 \\
.00 \\
.00 \\
.00 \\
.00\end{array}$ & $\begin{array}{l}0.00 \\
.00 \\
4.06 \\
.002 \\
.00 \\
.00 \\
.00 \\
.00 \\
.002 \\
.00 \\
.00 \\
.00 \\
.00 \\
.00 \\
.00 \\
.00 \\
.00 \\
1.60 \\
.25 \\
.00 \\
.00 \\
.00 \\
.00\end{array}$ & $\begin{array}{l}0.01 \\
.00 \\
4.06 \\
.002 \\
.00 \\
.00 \\
.00 \\
.00 \\
.002 \\
1.53 \\
.30 \\
.00 \\
.00 \\
.00 \\
.00 \\
.00 \\
.00 \\
1.60 \\
.25 \\
.00 \\
.00 \\
.00 \\
.00\end{array}$ & $\begin{array}{l}0.00 \\
.01 \\
.00 \\
.00 \\
.00 \\
.00 \\
.00 \\
.00 \\
.00 \\
.00 \\
.00 \\
.00 \\
.00 \\
.00 \\
.00 \\
.00 \\
.00 \\
.00 \\
.00 \\
.00 \\
4.26 \\
.00 \\
.00\end{array}$ & $\begin{array}{l}0.01 \\
.01 \\
.00 \\
.00 \\
.00 \\
.00 \\
.00 \\
.00 \\
.00 \\
1.53 \\
.30 \\
.00 \\
.00 \\
.00 \\
.00 \\
.00 \\
.00 \\
.00 \\
.00 \\
.00 \\
4.26 \\
.00 \\
.00\end{array}$ \\
\hline Baltimore City & .00 & .00 & .00 & .00 & .00 \\
\hline Total & 1.84 & 5.91 & 7.75 & 4.27 & 6.11 \\
\hline
\end{tabular}

